Northwestern University School of Law Northwestern University School of Law Scholarly Commons

Faculty Working Papers

2010

\title{
An Empirical Examination of Universal Jurisdiction for Piracy
}

Eugene Kontorovich

Northwestern University School of Law, e-kontorovich@law.northwestern.edu

Steven Art

Law Clerk, Judge Diane Wood

\section{Repository Citation}

Kontorovich, Eugene and Art, Steven, "An Empirical Examination of Universal Jurisdiction for Piracy" (2010). Faculty Working Papers. Paper 38.

http://scholarlycommons.law.northwestern.edu/facultyworkingpapers/38

This Article is brought to you for free and open access by Northwestern University School of Law Scholarly Commons. It has been accepted for inclusion in Faculty Working Papers by an authorized administrator of Northwestern University School of Law Scholarly Commons. 


\title{
“A Guantánamo on the Sea”: The Difficulty of Prosecuting Pirates and Terrorists
}

\author{
Eugene Kontorovich $\dagger$
}

No one wants a Guantánamo on the sea. ${ }^{1}$

— Franz Josef Jung, German Defense Minister

They can't stop us—we know international law. ${ }^{2}$

— Jama Ali, a Somali pirate

\section{INTRODUCTION}

In the summer of 2008, an epidemic of piracy broke out in the Gulf of Aden, off the Horn of Africa, with record numbers of ships attacked and captured. $^{3}$ The magnitude of the problem generated a response that on the surface appears to be a model of international cooperation. An unprecedented naval force, spearheaded by the United States and with contributions from a

Copyright (C) 2010 California Law Review, Inc. California Law Review, Inc. (CLR) is a California nonprofit corporation. CLR and the authors are solely responsible for the content of their publications.

$\dagger$ Associate Professor, Northwestern University Law School. The author thanks Steven Art for his extraordinary assistance in researching this Essay, and the Global Law Forum at the Jerusalem Center for Public Affairs for its support for an earlier version of this project. Avi Bell, Evan Criddle, Gregory McNeal, and Bernard Oxman provided helpful comments. This Essay was selected for presentation at the National Security Law Junior Scholar's Workshop at the University of Texas, sponsored by the International Committee of the Red Cross, and at the American Association of Law Schools annual meeting. Special thanks go to the commentators and other participants.

1. See Germany Calls for International Court to Prosecute Pirates, FoxNews.com, Dec. 23, 2008, http://www.foxnews.com/story/0,2933,471804,00.html (explaining why nations today are reluctant to act against pirates).

2. Jeffrey Gettleman, Pirates Outmaneuver Warships off Somalia, N.Y. Times, Dec. 15, 2008, at A6 ("Even if foreign navies nab some members of his crew, Mr. Jama said, he is not worried. He said his men would probably get no more punishment than a free ride back to the beach.”).

3. In 2008, the International Maritime Bureau of the International Chamber of Commerce reported an "unprecedented" wave of piracy in the Gulf of Aden, with 111 recorded attacks. See ICC Commercial Crime Services, IMB Reports Unprecedented Rise in Maritime Hijackings, Jan. 16, 2009, http://www.icc-ccs.org/index.php?option=com_content\&view=article\&id=332:imbreports-unprecedented-rise-in-maritime-hijackings\&catid=60:news\&Itemid=51. 
[Vol. 98:243

dozen nations, assembled in the Gulf of Aden. ${ }^{4}$ The U.N. Security Council unanimously authorized the use of force against pirates even in sovereign Somali territory. ${ }^{5}$ These developments could be seen as a high point for a new international legal order. Yet the international response has failed to control the outbreak of piracy. ${ }^{6}$ The countries policing the Gulf of Aden refuse to attack and often even to arrest the pirates. As the U.S. National Security Council wrote, "Somali-based piracy is flourishing because it is ...nearly consequence-free."7

The international law regarding piracy provides a uniquely favorable framework for its suppression. Under the doctrine of universal jurisdiction, which for centuries applied only to piracy, any nation can capture and try pirates it finds on the high seas. ${ }^{8}$ Yet none of the countries patrolling the coast of Somalia have chosen to exercise this authority. ${ }^{9}$ The frigates routinely apprehend pirates in the act, only to let them go. In at least one case, a North Atlantic Treaty Organization (NATO) warship came across suspected pirates in a broken boat and, pursuant to international norms concerning "distressed mariners," gave them a tow back to port. ${ }^{10}$ Several European nations have instructed their navies not to make any arrests. ${ }^{11}$ As a result, a few thousand largely illiterate brigands from one of the world's poorest countries have managed, with little more than small arms and rocket-propelled grenades

4. Mike Pfanz, Somali Pirate Attacks "Set to Increase" as Monsoon Eases, TelegraPH (U.K.), July 27, 2009.

5. See S.C. Res. 1816, U.N. Doc. S/RES/1816 (June 2, 2008); S.C. Res. 1838, U.N. Doc. S/RES/1838 (Oct. 7, 2008); S.C. Res. 1844, U.N. Doc. S/RES/1844 (Nov. 20, 2008); S.C. Res. 1846, U.N. Doc. S/RES/1846 (Dec. 2, 2008); S.C. Res. 1851, U.N. Doc. S/RES/1851 (Dec. 16, 2008).

6. See, e.g., Douglas R. Burgess, Jr., Op-Ed., Piracy Is Terrorism, N.Y. Times, Dec. 5, 2008, at A33 (observing that the question whether "the Somali pirates [are] ordinary criminals, or a quasi-military force .... has virtually paralyzed the navies called to police the Gulf of Aden").

7. National Security Council, Countering Piracy off the Horn of Africa: Partnership \& Action Plan 12 (2008) [hereinafter "Countering Piracy"].

8. The high seas are all parts of the sea not included in states' internal waters or territorial waters, which extend out 12 nautical miles, and the exclusive economic zone, which extends out 200 miles. United Nations Convention on the Law of the Sea arts. 3, 56(1), Dec. 10, 1982, 1833 U.N.T.S. 397, 400, 418 [hereinafter UNCLOS]. For purposes relevant to piracy, the high seas regime applies to the exclusive economic zone as well. See id. art. 56(1) (describing limited sovereign rights to natural resources in EEZ), art. 58(2).

9. See, e.g., John Helmer, Navies Stumped over Pirates off Somalia, Bus. DAY, June 3, 2009, available at http://www.businessday.co.za/articles/Content.aspx?id=72374 (describing Russia's unwillingness to use its universal jurisdiction statute against captured Somali pirates).

10. Bent Mikkelsen, Pirates Keep the Absalon Busy, ShipPING GaZette, Nov. 21, 2008, available at http://www.shipgaz.com/old/magazine/issues/2008/22/article2.php; Jeffrey Gettleman, Somalia's Pirates Flourish in a Lawless Nation, N.Y. Times, Oct. 31, 2008, at A1; see also UNCLOS, supra note 8, art. 98(1)(a)-(b).

11. See Gettleman, supra note 10; Justin Stares, Pirates Protected from EU Task Force by Human Rights, Telegraph (London), Nov. 19, 2008; Marie Woolf, Pirates Can Claim UK Asylum, Times OnLine, Apr. 13, 2008, http://www.timesonline.co.uk/tol/news/uk/ article3736239.ece. 
(RPGs), ${ }^{12}$ to shrug off the efforts of an overwhelming naval force. ${ }^{13}$ The piracy epidemic worsened steadily even after the global armada assembled in the Gulf in late 2008. ${ }^{14}$

As former U.S. Secretary of State Condoleezza Rice told the U.N. Security Council, international law provides "sufficient legal authority with which to apprehend and prosecute pirates."15 What is lacking, said Secretary Rice, is the "political will and capacity." 16 Various second-order international legal rules, norms, and expectations pull in the opposite direction, frustrating antipiracy efforts. International rules make detention and prosecution so costly that setting pirates loose seems preferable. ${ }^{17}$

Many of the legal issues that prevent states from effectively suppressing pirates also plague responses to international terrorism. Pirates and terrorists fall in the gray zone between military combatants and civilians. Thus the antipiracy campaign and the so-called War on Terror both raise questions about the legal status of conflicts between states and diffuse armed networks with international operations. Issues that have impeded countries' efforts on both these fronts include: potential confusion about pirates' prisoner of war (POW) status, the use of prolonged detention, rendition of suspects to countries with poor human rights records, claims of abuse by detainees, the difficulty of proving in civilian courts cases arising from active military operations, and the legality of "targeted killings" of suspected hostile civilians.

The legal obstacles come from international humanitarian law, including the Geneva Conventions, human rights treaties, international refugee law, the

12. See Jamal Osma, 'We Are Hungry. There Is No Government, No Economy, So It Is a Good Way to Earn Money', Times (London), Dec. 12, 2008, at 54 ("Pirates are usually in their twenties, illiterate, attracted by the prospect of a lucrative life and are prepared to get rich or die trying.”).

13. Jeffrey Gettleman, Somali Pirates Tell Their Side: They Want Only Money, N.Y. Times, Sept. 30, 2008, at A6.

14. See Pfanz, supra note 4.

15. See Press Release, Security Council, Security Council Authorizes States to Use LandBased Operations in Somalia, as Part of Fight Against Piracy off Coast, Unanimously Adopting 1851, U.N. Doc. SC/9541 (Dec. 16, 2008) [hereinafter S.C. Res. 1851 Press Release] (statement of U.S. Sec'y of State Condoleezza Rice).

16. Id.

17. See Jim Garamone, Mullen Shocked by Pirate Attack on Supertanker, Am. ForCES Press Service, Dep'T OF Def., Nov. 17, 2008, http://www.defenselink.mil/news/ newsarticle.aspx?id=51972 (quoting the Chairman of the U.S. Joint Chiefs of Staff: "One of the challenges that ... you have in piracy clearly is, if you are intervening and you capture pirates, is there a path to prosecute them?"); Nicolas Kulish, Legal Hurdles in West Slow Pursuit of Pirates, N.Y. Times, Nov. 29, 2008, at A8. In the same vein, Denmark, a leading maritime nation, said at a U.N. meeting, that dealing with the pirates required "further deliberations on issues with regard to detention and prosecution of pirates" and stressed the need for a "clear legal infrastructure, both for extradition and prosecution of perpetrators." See Danish Maritime AuthoRITY, RePORT ON the ioist Session of the International Maritime Organization (Nov. 20, 2008), available

http://www.dma.dk/news/Sider/SessionwithDanishimprintheldinUN\%E2\%80\%99sInternationalM aritimeOrganization(101stsessionoftheCouncil).aspx. 
U.N. Convention on the Law of the Sea (UNCLOS), and other sources. None of these measures were designed to obstruct antipiracy efforts; the conventions were generally adopted without any thought about a resurgence of high seas piracy. But the growth of international legal norms that limit state authority and provide greater protections for individuals make it harder for nations to perform the oldest and perhaps most basic law enforcement function in international law: preventing piracy.

The failure of the antipiracy campaign offers lessons about one of the most prominent and contentious issues of the day: whether the ordinary criminal process can effectively deal with alleged, irregular combatants captured abroad. ${ }^{18}$ The Obama administration has begun transferring detainees from Guantánamo Bay, where they may have faced military commission proceedings, to the mainland for trials before civilian courts. ${ }^{19}$ The failure of similar measures in the battle against piracy suggests some of the difficulties those plans might face. Western countries' refusal to prosecute pirates they capture stems from their concern about the difficulties of applying regular criminal processes to such irregular forces.

The Somali piracy problem provides an excellent case study of the effects of various international legal rules, because one would expect international law to be more effective here than with terrorism and unlawful combatants. Piracy is the paradigmatic crime for which international law authorizes and even requires universal enforcement and punishment. Terrorism, on the other hand, is not an international offense. ${ }^{20}$ Unlike the War on Terror, the antipiracy campaign has not been the subject of intense domestic or international dispute; a coalition of diverse states has sent forces to interdict Somali pirates. The only state whose sovereign interests are at stake, Somalia, has made clear that it has no intention of intervening on behalf of the pirates. ${ }^{21}$

Similarly, pirates lack ideological fellow-travelers who might draw attention to their cases. Terrorists have political goals and thus sympathizers, lobbyists, and often state support. Furthermore, the U.N. Security Council resolutions authorized robust action against Somali pirates, both at sea and in

18. Daphne Eviatar, 9/11 Masterminds Could Face Trial in Federal Court, WAsh. INDEP., Oct. 21, 2009, available at http://washingtonindependent.com/64590/911-masterminds-couldface-trial-in-federal-court; see also Jack L. Goldsmith \& Neal Katyal, Op-Ed., The Terrorists' Court, N.Y. Times, July 11, 2007, at A19.

19. Obama Plans U.S. Terror Trials to Replace Guantanamo Prisons, USA TodaY, Nov. 11, 2008, available at http://www.usatoday.com/news/washington/2008-11-11-obamaguantanamo_N.htm.

20. See, e.g., United States v. Yousef, 327 F.3d 56, 97 (2d Cir. 2003) ("We . . . further hold that customary international law currently does not provide for the prosecution of 'terrorist' acts under the universality principle, in part due to the failure of States to achieve anything like consensus on the definition of terrorism.").

21. See S.C. Res. 1846, U.N. Doc. S/RES/1846 (Dec. 2, 2008); S.C. Res. 1851, U.N. Doc. S/RES/1851 (Dec. 16, 2008) (noting the Somali government's approval of the international antipiracy effort contemplated by the resolutions). 
sovereign Somali territory. The Security Council passed five such resolutions in $2008,{ }^{22}$ more than on any other issue, including the Israeli-Arab conflict. ${ }^{23}$ Unlike terrorism, which is often directed at a particular nation, piracy directly injures the commerce of the many countries whose trade passes through the Gulf of Aden; states suffer direct losses and thus have private incentives to intervene.

Moreover, the practicalities of fighting piracy are less daunting than terrorism: pirates have little training, float around the seas in open boats, and thus are easier to catch than terrorists. Finally, while Kenya is now hosting trials of some captured pirates, many third-party states are not eager to try or jail terrorists or other serious international criminals out of fear that their friends might retaliate. Even U.S. allies sympathetic to President Obama's planned closure of Guantánamo refused to accept detainees from the base. ${ }^{24}$ Similarly, the Netherlands agreed to host the war crimes trial of former Liberian President Charles Taylor, but refused to host his imprisonment if he is convicted. ${ }^{25}$

The discussion proceeds as follows. Part I describes the eruption of piracy in the Gulf of Aden and the multifaceted international response. Part II outlines the powerful international legal tools available to combat piracy. Part III explains the countervailing international norms and considerations that have undermined the effectiveness of the regime described in Part II. The Conclusion places the failure to assert universal jurisdiction against piracy in the broader context of universal jurisdiction against higher profile and more politically sensitive offenses such as war crimes and genocide. ${ }^{26}$

22. See S.C. Res. 1816, U.N. Doc. S/RES/1816 (June 2, 2008); S.C. Res. 1838, U.N. Doc. S/RES/1838 (Oct. 7, 2008); S.C. Res. 1844, U.N. Doc. S/RES/1844 (Nov. 20, 2008); S.C. Res. 1846, U.N. Doc. S/RES/1846 (Dec. 2, 2008); S.C. Res. 1851, U.N. Doc. S/RES/1851 (Dec. 16, 2008).

23. See United Nations Security Council Resolutions 2008, available at http://www.un.org/Docs/sc/unsc_resolutions08.htm.

24. See Guantanamo Issue Looms Large for Europe, Deutsche Welle, Feb. 27, 2009, http://www.dw-world.de/dw/article/0,,4059693,00.html ("Many European countries are deeply concerned about having people who pose a potential security risk at large.”); Judy Dempsey \& Stephen Castle, EU Nations Divided On Taking Guantánamo Detainees, InT'l Herald Trib., Jan. 22, 2009, available at http://www.nytimes.com/2009/01/22/world/europe/22iht-germany.4.1 9609842.html; Peter Finn, Administration Makes Progress on Resettling Detainees, WASH. Post, Aug. 20, 2009, at A3 (reporting that Uighur detainees have been transferred to Bermuda and Palau, but not to European nations); Robert Marquand, Closing Guantánamo: Will Europeans Take Detainees?, Christian Sci. Monitor, Jan. 23, 2009, at 5.

25. See Rory Carroll, Charles Taylor Flown to the Hague to Face War Crimes Trial, GuARDian (London), June 21, 2006, at 23.

26. This Essay does not advocate any alternative approach to either piracy or transnational terror, but rather seeks explain the nature of the legal obstacles common to both. 
[Vol. 98:243

\section{I}

\section{AN OLD PROBLEM REVIVED}

\section{A. The Piracy Epidemic}

A series of spectacular hijackings in the Gulf of Aden propelled Somali piracy to the forefront of international attention. In late 2008 and early 2009, pirates hijacked a Ukrainian ship carrying battle tanks and arms to Kenya, ${ }^{27}$ a Saudi tanker filled with crude oil, ${ }^{28}$ a chemical tanker, ${ }^{29}$ and numerous U.N. ships carrying international relief supplies. ${ }^{30}$ Pirates also fired on an Americanowned cruise liner ${ }^{31}$ and even seized one of the few U.S.-flagged ships on the high seas. ${ }^{32}$ These are some of the more notorious incidents in a rapidly escalating epidemic. ${ }^{33}$ While attacks on international shipping in the Gulf of Aden have only recently received significant public attention, they have been escalating since the Somali government collapsed in the early 1990s, ${ }^{34}$ growing in frequency and sophistication beginning in $2005 .{ }^{35}$ In 2008, the attacks increased more than threefold over the previous year. ${ }^{36}$ The geographic scope of the attacks also widened, with hijackings occurring in international waters hundreds of miles offshore. ${ }^{37}$ The number of attacks in the first half of 2009 exceeded totals for all of 2008, with expectations of a further surge in the fall. ${ }^{38}$

27. Jeffrey Gettleman, Somali Pirates Capture Tanks and Unwanted Global Notice, N.Y. Times, Sept. 27, 2008, at A1.

28. Xan Rice, Pirates Anchor Hijacked Supertanker off Somalia Coast, GuARdian (London), Nov. 18, 2008, available at http://www.guardian.co.uk/world/2008/nov/18/somalia-oil.

29. Philippine Tanker Hijacked By Pirates, N.Y. Times, Nov. 11, 2008, at A14.

30. Jeevan Vasagar, Pirates Hijack Tsunami Aid Ship, Guardian Unlimited, July 1, 2005, http://www.guardian.co.uk/society/2005/jul/01/internationalaidanddevelopment.internationalnews.

31. U.S. Cruise Ship Escapes Fire from Pirates in Gulf of Aden, N.Y. Times, Dec. 2, 2008, at A14.

32. Mark Mazzetti \& Sharon Otterman, U.S. Captain Is Hostage of Pirates; Navy Ship Arrives, N.Y. Times, Apr. 9, 2009, at A6.

33. See, e.g., Int'l Chamber of Commerce Commercial Crime Servs., Pirate Attacks off Somalia Already Surpass 2008 Figures (2009), available at http://www.iccccs.org/index.php?option=com_content\&view=article\&id=352:pirate-attacks-off-somalia-alreadysurpass-2008-figures\&catid=60:news\&Itemid=51.

34. See Gettleman, supra note 10.

35. Peter Lehr \& Hendrick Lehmann, Somalia-Pirates' New Paradise, in Violence AT Sea: Piracy in the Age of Global Terrorism 1-3, 16 (Peter Lehr ed., 2007).

36. Roughly 111 ships were attacked in 2008. Int'L Chamber of Commerce Commercial Crime Servs., supra note 33.

37. The Sirius Star, a Liberian-flagged oil tanker hijacked in November 2008, was on its way around the Cape of Good Hope-not through the Suez Canal—when it was hijacked more than 450 nautical miles from shore. Robert F. Worth, Pirates Seize Saudi Tanker off Kenya, N.Y. Times, Nov. 18, 2008, at A6.

38. Gregory Viscusi, Somali Piracy to Pick Up After Monsoon, Task Force Chief Says, BloomberG, July 27, 2009, http://www.bloomberg.com/apps/news?pid=20601100\&sid= aDZfefl5fcpM (noting that twenty-eight of the attacks succeeded in seizing a ship); Pfanz, supra note 4 . 
The September 2008 hijacking of the arms-laden Faina triggered a new level of international concern. "With the seizure of the Ukrainian ship," said the U.N. Special Representative for Somalia, "a new line has been crossed. This act should not and will not be rewarded." ${ }^{39}$ The U.S. Navy diverted several vessels from counterterrorism operations to corner the ship. ${ }^{40}$ One officer wryly noted that in the pursuit, there was one destroyer for each pirate. ${ }^{41}$ Despite being surrounded, the pirates eventually received a multimillion-dollar ransom and escaped. ${ }^{42}$

The U.N. Security Council responded with a series of resolutions that authorized increasingly broad encroachments into Somali territory. On December 16, 2008, the Council passed its strongest resolution, ${ }^{43}$ drafted and promoted by the United States, which extended previous authorizations of military force to operations on the Somali mainland. This gave coalition navies a tool that pirate hunters have lacked for centuries ${ }^{44}$ and marked the first time the Council authorized armed action against pirates in sovereign territory.

\section{B. The Grand Armada}

In response to the piracy problem, NATO nations, along with other powers, began sending warships to patrol the Gulf of Aden. ${ }^{45}$ By the end of 2008, twenty-three nations had committed vessels. ${ }^{46}$ The force was augmented by the first naval force ever deployed by the European Union (EU), ${ }^{47}$ as well as

39. See Press Release, U.N. Political Office for Somalia, Somalia: SRSG Statement on Piracy (Sept. 29, 2008), available at http://www.reliefweb.int/rw/rwb.nsf/db900SID/VDUX7JXLA7?OpenDocument.

40. Jamey Keaten, Developed Countries Push Back vs. Pirates, Associated Press, Oct. 4, 2008, available at http://www.iht.com/articles/ap/2008/10/04/europe/EU-BattlingPiracy.php?page $=1$.

41. See John Patch, The Overstated Threat, U.S. NAv. Inst. Proceedings, Dec. 2008, at 34-39.

42. Jeffery Gettleman \& Mohammed Ibrahim, Somali Pirates Get Ransom and Leave Arms Freighter, N.Y. Times, Feb. 6, 2009, at A6.

43. See S.C. Res. 1851, U.N. Doc. S/RES/1851 (Dec. 16, 2008). Chapter VII of the U.N. Charter allows the Security Council to respond to threats to international peace by a variety of means, including authorizing military force. See U.N. Charter arts. 39, 41-42. Concerns raised by other Council members led the United States to withdraw draft language referring to operations in Somali "airspace," though the United States maintained that the resolution still permitted entry into Somali airspace for bombing and missile strikes. See U.S. Says Piracy Resolution Allows for Air Strikes in Somalia, Agence France Press, Dec. 17, 2008, http://www.infowars.com/us-sayspiracy-resolution-allows-for-air-strikes-in-somalia/.

44. See, e.g., Peter Earle, The Pirate Wars 237-45 (2003) (explaining that, during the eighteenth and nineteenth centuries, Britain and the United States were unable to stamp out Caribbean pirates because, among other things, they lacked Spanish permission to seek out landbased hideouts in Cuba and other islands).

45. Keaten, supra note 40.

46. Xan Rice, U.S. Launches Anti-Piracy Naval Force to Combat Hijackings off Somalia, GuARDian UnLimited, Jan. 9, 2009, http://www.guardian.co.uk/world/2009/jan/09/piracysomalia-us-navy.

47. Richard Norton-Taylor, British Warship to Lead EU Armada into Gulf of Aden, 
Russian and Indian warships ${ }^{48}$ and the first modern Chinese naval deployment to another region. ${ }^{49}$ Yet, the results so far are not encouraging. Despite these international efforts, the pirates still threaten to scare shipping away from a waterway that carries 7.5 percent of the world's seaborne trade and 30 percent of Europe's oil. ${ }^{50}$

Pirate attacks have grown even bolder since the international enforcement efforts began. ${ }^{51}$ At a U.N. Security Council meeting in December 2008, world leaders admitted that their antipiracy efforts had failed. While the international community had done "quite a lot," the Russian Foreign Minister observed, "piracy went unpunished."52 Secretary Rice agreed, saying pirates enjoyed "impunity," partially because of the problems with "the detention and prosecution of captured pirates." ${ }^{\text {. }} 3$

A U.S. Coast Guard admiral recently summarized the problems for Congress:

Somali pirates to date have suffered few consequences, even when they were apprehended. Frequently, the navies or other forces that apprehended pirates were from states outside the region, and faced significant legal ... challenges ... if they wished to bring pirates to justice in their courts. Thus, pirates are often not held accountable for their crimes and quickly make their way back to the Somali coast where they continue their piratical activities. ${ }^{54}$

Similarly, the pirates lack reservations about capturing civilian crews. In 2008, pirates took 815 crew members hostage off the coast of Africa; in the first half of 2009, another 561 were taken hostage and 6 were killed. ${ }^{55}$ Subsequent Parts will show how the naval campaign's failure to combat these attacks can be attributed in part to a lack of a legal basis for initiating hostilities against

GuARDian (London), Nov. 20, 2008, at 29.

48. Viscusi, supra note 38.

49. Mark McDonald, Chinese Warships Sail, Loaded for Pirates, N.Y. Times, Dec. 26, 2008, at A6.

50. BBC News, The Suez Crisis: Key Maps, July 21, 2006, http://news.bbc.co.uk/ 2/hi/middle_east/5195068.stm ("About 7.5\% of world sea trade is carried via the canal today."); Somali Pirates Risk Choking Key World Trade Route, Reuters, Apr. 15, 2009, available at http://www.reuters.com/article/newsOne/idUSTRE53E2JR20090415 (“Around 30\% of Europe's oil goes through the Gulf of Aden and Red Sea.").

51. Nick Wadhams, As Somali Pirates Get Bolder, Policing Them Gets Tougher, Time.com, Nov. 19, 2008, http://www.time.com/time/world/article/0,8599,1860404,00.html.

52. S.C. Res. 1851 Press Release, supra note 15 (statement of Russian Minister for Foreign Affairs Sergei Lavrov).

53. Id. (statement of U.S. Sec'y of State Condoleezza Rice).

54. International Piracy on the High Seas: Hearing Before the H. Subcomm. on Coast Guard \& Maritime Transportation, 111th Cong. (2009) (statement of Rear Admiral William Baumgartner) [hereinafter Baumgartner Statement].

55. World Pirate Attacks More Than Double This Year, SeattleTimes.Com, July 15, 2009, http://seattletimes.nwsource.com/html/nationworld/2009472715_apaspiracyworldattacks. html. As of this writing, pirates continued to hold nearly 200 crewmembers from 11 vessels. Lori Johnston, Q \& A on the News, AtLANTA J.-Const., July 21, 2009, at 2A. 
suspected pirates and daunting obstacles in prosecuting them. ${ }^{56}$

It bears noting that, in four instances, captured Somali pirates were taken to Western countries for trial—but only when they specifically attacked that state's vessels. In one case, pirates seized a French yacht. Paris responded with extraordinary vigor, sending commandos into the mainland of Somalia to identify the pirates, and bringing them back to Paris for trial. ${ }^{57}$ Similarly, the Netherlands is trying a group of pirates that attacked a Dutch-flagged vessel, ${ }^{58}$ and the United States is prosecuting the surviving pirate from the hijacking of the Maersk Alabama, an American cargo ship. ${ }^{59}$ This suggests nations are willing to accept the burden of prosecuting pirates when it involves their direct and immediate interests_-but not when it involves universal jurisdiction.

II

\section{LEGAL TOOLS FOR FIGHTING PIRACY}

\section{A. Universal Jurisdiction}

International law gives ample license for pursuing and prosecuting pirates. ${ }^{60}$ For hundreds of years, international law has treated the pirate as a hostis humani generis - an enemy of all mankind. ${ }^{61}$ Several factors account for pirates' special jurisdictional treatment. ${ }^{62}$ Pirates, by definition, do not

56. See, e.g., Gettleman, supra note 10; Jason Keyser, Guarded Shipping Corridor Limiting Somali Piracy, Associated Press, Nov. 10, 2008, available at http://www.usatoday.com/news/ world/2008-11-10-3512568313_x.htm (reporting that sixty pirates have been released since October 2008 alone "because no country has been willing to bring them to trial"); Mikkelsen, supra note 10 .

57. France Raid Ship After Crew Freed, BBC News, Apr. 12, 2008, http://news.bbc.co.uk/ 2/hi/africa/7342292.stm.

58. Bruno Waterfield, Somali Pirates Embrace Capture as Route to Europe, TelegrapH (U.K.), May 19, 2009, http://www.telegraph.co.uk/news/worldnews/piracy/5350183/Somalipirates-embrace-capture-as-route-to-Europe.html. The Danish Navy captured and held the suspects, but Denmark would not exercise universal jurisdiction over piracy. Sebastiaan Gottlieb, The Dutch Want Pirates in Court, Radio Netherlands, Jan. 16, 2009, http://www.radionetherlands.nl/currentaffairs/090116-piracy-trial.

59. Joseph Goldstein, Makin' 'em Walk the Plank, A.B.A. J., July 2009, at 16-17. The United States charged the alleged pirate with additional attacks against other, unidentified but presumably non-American vessels. See Benjamin Weiser, Somali Man Is Charged in 2 More Ship Hijackings, N.Y. Times, Jan. 12, 2010, at A26. Given the existing charges of piracy against an American vessel, the additional charges can be thought of as "pendent" or "supplemental" universal jurisdiction, rather than naked universal jurisdiction. See, e.g., Eugene Kontorovich, The "Define and Punish" Clause and the Limits of Universal Jurisdiction, 103 Nw. U. L. Rev. 149, 180 (2009) (explaining unusual American piracy prosecution from the 1790s as a possible example of pendent universal jurisdiction).

60. S.C. Res. 1851 Press Release, supra note 15 (statement of U.S. Sec'y of State Condoleezza Rice) (observing that international treaties gave "sufficient legal authority with which to apprehend and prosecute pirates, but that political will and capacity was often lacking”).

61. See Edward CoKe, 3 Institutes on the Laws of England 113 (1797); Lassa Oppenheim, International Law: A Treatise § 272, at 325-26 (1905); see also Restatement (Second) of Foreign Relations LaW of the United States § 34 cmt. b (1965).

62. See generally Eugene Kontorovich, Implementing Sosa v. Alvarez-Machain: What 
[Vol. 98:243

discriminate among targets based on nationality and thus endanger the trade of all countries. ${ }^{63}$ Their attacks also raise the prices of commodities, so that even nations not directly involved in shipping suffer. ${ }^{64}$ Moreover, cargo ships are usually owned by a corporation in one state, fly the flag of a second state, and carry cargo destined for multiple other states. Further, ships often are crewed by people from still other states. ${ }^{65}$ Piracy implicates the interests of all of those countries.

Equally important, pirates are not endorsed by their home countries. ${ }^{66}$ This means that when some other state seeks to prosecute them, his or her own country will likely not protest. Based on the example of piracy, modern human rights law has attempted to extend universal jurisdiction to crimes with political motivations and governmental perpetrators, such as war crimes and torture. ${ }^{67}$ Doing so has often raised the hackles of defendants' home governments. ${ }^{68}$ By contrast, no home government has much solicitude for pirates, who are considered mere robbers.

\section{B. The United Nations Convention on the Law of the Sea (UNCLOS)}

The United Nations Convention on the Law of the Sea (UNCLOS), ratified by almost every country in the world, codifies the universal jurisdiction status of piracy. ${ }^{69}$ UNCLOS defines piracy more broadly than did the customary law of nations by including "any illegal acts of violence or detention, or any act of depredation, committed for private ends. ${ }^{, 70}$ Thus, UNCLOS makes assault and murder on the high seas universally punishable. Under the

Piracy Teaches About the Limits of the Alien Tort Statute, 80 Notre Dame L. Rev. 111, 139-53 (2004) (explaining the reasons that piracy was a universal jurisdiction offense).

63. See, e.g., United States v. Yousef, 327 F.3d 56, 104 (2d Cir. 2003) (observing that piracy has long been subject to universal jurisdiction in part "because of the threat that piracy poses to orderly transport and commerce between nations").

64. For example, the November 2008 hijacking of a Saudi Oil tanker that held two million barrels of oil (more than one quarter of Saudi Arabia's daily exports) helped to raise global oil prices more than one dollar, to fifty-eight dollars a barrel. See Raissa Kaslowsky \& Simon Webb, Somali Pirates Seize Saudi Tanker Carrying \$100 Million in Oil, Wash. Post, Nov. 17, 2008, at A24.

65. Id. ("A single piratical attack often affects the interests of numerous countries, including the flag State of the vessel, various States of nationality of the seafarers taken hostage, regional coastal States, owner States, and cargo owner, transshipment, and destination States.”).

66. Kenneth C. Randall, Universal Jurisdiction Under International Law, 66 Tex. L. Rev. 785, 793 (1988).

67. See Eugene Kontorovich, The Piracy Analogy: Modern Universal Jurisdiction's Hollow Foundation, 45 HARv. INT'L L.J. 183, 184, 197-207 (2004).

68. See, e.g., Edward Wong, China Protests U.S. Rights Suit Against a Leader, N.Y. Times, Sept. 5, 2000, at A4.

69. UNCLOS, supra note 8, art. 105. For the comprehensive list of ratifications, see http://www.un.org/Depts/los/reference_files/chronological_lists_of_ratifications.htm\#The\%20 United\%20Nations\%20Convention\%20on\%20the\%20Law\%20of\%20the\%20Sea.

70. Id. art. 101(a). While the United States has not ratified the third and most recent version of UNCLOS, it is party to an earlier incarnation with identical piracy provisions. See Convention on the Territorial Sea and Contiguous Zone, Apr. 29, 1958, 516 U.N.T.S. 205. 
older customary norm, only robbery counted as piracy, and thus more severe crimes, such as murder, fell outside the scope of international law. ${ }^{71}$

UNCLOS also requires nations to combat piracy. The drafters' commentary stresses that "any State having an opportunity [to take] measures against piracy, and neglecting to do so, would be failing in a duty laid upon it by international law."72 It also favorably cites the Harvard Draft Convention on Piracy, which went so far as to state that legal claims could be brought against any nation that does not take sufficient steps to bring pirates to justice. ${ }^{73}$ Yet Article 105 makes clear that prosecution itself is not obligatory. ${ }^{74}$

In some ways, however, UNCLOS makes fighting piracy more difficult. ${ }^{75}$ The central provisions of the treaty extend nations' territorial seas to twelve miles from the coast, a significant expansion of the traditional three-mile zone. ${ }^{76}$ Because the international law of piracy applies only on the "high seas," UNCLOS has the unintended effect of reducing the area where piracy can be internationally policed. ${ }^{77}$ This change allows pirates to take advantage of the territorial waters of weak or failed states. The expanded territorial waters cause even greater problems in gulfs, straits, and archipelagoes, where international shipping must pass through an area bounded on several sides by sovereign waters. Almost all Somali pirate attacks against international shipping take place far outside that country's twelve-mile territorial sea, ${ }^{78}$ and thus this feature of UNCLOS cannot be seen as facilitating their activities. Moreover, the Security Council has authorized international forces to "enter the territorial

71. See, e.g., United States v. Furlong, 618 U.S. (5 Wheat.) 184 (1820).

72. See Report of the International Law Commission to the General Assembly, 11 GAOR Supp. (No. 9) at art. 38 cmt. 2, U.N. Doc. A/3159 (1956), reprinted in [1956] 2 Y.B. Int'l Comm'n 253, at 282, A/CN.4/SER.A/1956/Add.l [hereinafter RePORT OF THE INT'L LAw CoMm'N].

73. See id. art. 38 cmt. 1, at 282; see also Harvard Research in Int'l Law, Draft Convention and Comment on Piracy, 26 Am. J. InT'L L. 739 (Supp. 1932) [hereinafter Harvard Draft Convention].

74. See Tullio Treves, Piracy, Law of the Sea, and Use of Force: Developments off the Coast of Somalia, 30 Eur. J. Int'L L. 399, 408 (2009); NATO Parliamentary Assembly, The Growing Threat of Privacy to Regional and Global Security, 169 CDS 09 E 97 (2009), available at http://www.nato-pa.int/default.asp?SHORTCUT=1770.

75. For other potential complications related to UNCLOS, see infra notes 111, 206-210 and accompanying text.

76. UNCLOS, supra note 8, art. 3; see MARK W. JANIS, AN InTRODUCTION to INTERNATIONAL LAW 216-22 (describing transition from three- to twelve-mile seas).

77. Martin Murphy, Piracy and UNCLOS: Does International Law Help Regional States Combat Piracy?, in Violence at Sea: Piracy in the Age of Global Terrorism 161-63 (Peter Lehr ed., 2007).

78. Two of the leading piracy problem areas are the Gulf of Aden (located in the Arabian Sea between Somalia and Yemen) and the Straits of Malacca (in the Indian Ocean between Malaysia and Singapore), both chokepoints for international shipping. See DeP'T of EnERgy, Energy Info. Admin., Country Analysis Briefs: World Oil Transit Chokepoints (Jan. 2008), available at http://www.eia.doe.gov/cabs/World_Oil_Transit_Chokepoints/Full.html (listing both the Strait of Malacca and Bab el Mandeb, the narrow strait separating the Gulf of Aden and the Red Sea, as "world oil transit chokepoints"). 
waters of Somalia for the purpose of repressing acts of piracy" and to "use ... all necessary means to repress act of piracy.",79

\section{The Suppression of Unlawful Acts Treaty}

An additional source of jurisdiction, which partially overlaps with UNCLOS and existing international law concerning piracy, is the Convention for the Suppression of Unlawful Acts Against the Safety of Maritime Navigation (SUA). ${ }^{80}$ SUA has 156 signatories, whose merchant marines comprise roughly 95 percent of the world's shipping tonnage. ${ }^{81}$ The U.N. Security Council resolutions on Somali piracy have stressed the availability of jurisdiction under SUA. ${ }^{82}$ Prosecution solely under the treaty, however, has been limited to a single obscure case against a deranged cook who commandeered a fishing trawler. ${ }^{83}$

SUA requires these signatories ${ }^{84}$ to prosecute anyone who "seizes or exercises control over a ship by force or threat of force or any other form of intimidation., ${ }^{85}$ Jurisdiction is also readily available for countries whose nationals are seized, threatened, injured, or killed during an attack. ${ }^{86}$ SUA has certain advantages over UNCLOS as a basis for jurisdiction. First, it covers acts in territorial waters, not just on the high seas. ${ }^{87}$ Second, it makes the exercise of jurisdiction mandatory in some circumstances. ${ }^{88}$ Yet while SUA "obliges contracting governments either to extradite alleged offenders or submit cases to their competent authorities for the purpose of prosecution," refusing to take custody of pirates in the first place prevents such obligations from attaching. UNCLOS, in contrast, requires nations to take active measures against piracy, but does not mandate prosecution. ${ }^{89} \mathrm{~A}$ combination of the two treaties, however, could require states to prosecute in some instances. Some states

79. S.C. Res. 1816, art. 7, U.N. Doc. S/RES/1816 (June 2, 2008).

80. 27 I.L.M. 668 (1988), entered into force 1992 (also known as the "Rome Convention"). The treaty was enacted in response to the Achille Lauro hijacking of 1985, in which Palestinian terrorists hijacked an Italian cruise liner, having come on board as passengers. See Malvina Halberstam, Terrorism on the High Seas: The Achille Lauro, Piracy and the IMO Convention on Maritime Safety, 82 AM. J. INT'L L. 269, 270-72 (1988).

81. See Int'l Maritime Org., Summary of Status of Convention: As of 31 January 2010, http://www.imo.org/Conventions/mainframe.asp?topic_id=247.

82. See, e.g., Sec. Res. 1846, ๆ 15, U.N. Doc. S/RES/1846 (Dec. 2, 2008).

83. See United States v. Shi, 525 F.3d 709 (9th Cir. 2008); see also Eugene Kontorovich, International Decisions-United States v. Shi, 525 F.3d 709, 103 AM. J. INT’L. L. 734 (2009).

84. 27 I.L.M. 668 art. 6(4).

85. Id. art. 3(a).

86. Id. art. 6(2)(b).

87. See id. art. 4.

88. SUA also explicitly gives jurisdiction over covered offenses to all signatory nations, regardless of the nationality of the vessels involved. See id. art. 6(4). See also infra notes 207-19 and accompanying text.

89. See Treves, supra note 74, at 408; NATO Parliamentary Assembly, supra note 74 169 CDS 09 E $\uparrow 37$ (2009). 
implement UNCLOS's duty to "cooperate ... in the repression of piracy" by taking police measures against piracy. ${ }^{90}$ If patrolling states that are SUA signatories take pirates into custody, they would then have a duty to extradite or punish.

\section{Trials in Other Countries}

Although nations patrolling the Gulf of Aden have resisted bringing pirates into their domestic courts, they have looked for other places to send them. In 2006, the United States sent a group of pirates captured by the USS Churchill to Kenya for trial in a closely watched test case. ${ }^{91}$ While their trials eventually occurred without major complications and the pirates were convicted, ${ }^{92}$ such transfers did not immediately become regular procedure in Kenya. At the height of the piracy surge in December 2008, however, Britain signed a memorandum of understanding with Kenya, formalizing an arrangement whereby captured pirates would be turned over to the latter for trial. ${ }^{93}$ In the subsequent months, the United States, the EU, and Denmark entered into similar arrangements with Kenya ${ }^{94}$ As of mid-2009, roughly one hundred pirates had been transferred to Kenya. ${ }^{95}$

Western nations see Kenya as conveniently situated to become an informal regional piracy court. ${ }^{96}$ Yet Kenya is at best a stopgap solution. Officials in Nairobi have made clear that their willingness to accept pirates is limited. ${ }^{97}$ Kenya does not relish doing the rest of the world's dirty work. ${ }^{98}$ The detention and prosecution of hundreds of foreign Muslims who have committed

90. UNCLOS, supra note 8, art. 100.

91. Michael Bahar, Attaining Optimal Deterrence at Sea: A Legal and Strategic Theory for Naval Anti-Piracy Operations, 40 VAND. J. Transnat'L L. 1, 36 (2007).

92. See id.; James Kraska \& Brian Wilson, Fighting Pirates: The Pen and the Sword, WORLD POL'y J., Winter 2008, at 46-47 (noting pirates received seven-year sentences).

93. Foreign \& Commonwealth Office (U.K), Prisoner Transfer Agreements, http://www.fco.gov.uk/en/global-issues/conflict-prevention/piracy/acks.

94. David Morgan, U.S. Delivers Seven Somali Pirate Suspects to Kenya, Reuters, Mar. 5, 2009, http://www.reuters.com/article/worldNews/idUSTRE52480N20090305.

95. See Catherine Philp, Captured Somali Pirates Are Being Dumped in Kenya, Officials Say, Times (London), June 12, 2009, at 41; see also Celestine Achieng, U.S. Navy Hands over 17 Pirates to Kenya, Reuters, June 10，2009, http://www.reuters.com/article/africaCrisis/ idUSLA1052558.

96. Jeffrey Gettleman, The West Turns to Kenya as Piracy Criminal Court, N.Y. Times, Apr. 24, 2009, at A8.

97. James Butty, Kenyan Foreign Minister Sheds Light on U.S.-Kenya Piracy Agreement, TURKISH WeEKLY, Jan. 28, 2009, available at http://www.turkishweekly.net/news/63755/kenyanforeign-minister-shed-light-on-u-s-kenya-piracy-agreement-.html (quoting Kenyan foreign minister as saying the Memorandum of Agreement with the United States is "not an open door for dumping pirates onto Kenya soil because it will not be acceptable").

98. Id.; James Thuo Gathii, Kenya Has No Duty to Try Pirates Arrested Elsewhere, Bus. DAILY (Nairobi), Apr. 15, 2009, available at http://multimedia.marsgroupkenya.org/?StoryID= 252749\&page $=3 \& p=$ Lari (noting that trying pirates in Kenyan courts will slow domestic trials, and describing Kenya's agreements with Western states as efforts by the latter to "offshore" their responsibilities for prosecuting pirates to Kenya). 
no particular crime against Kenya threatens to irritate its relations with Somalia's and its own Muslim populations. ${ }^{99}$ So far, however, patrolling nations have been unsuccessful in their efforts to find other nearby states to host piracy prosecutions. ${ }^{100}$ Indeed, the Seychelles, often mentioned as a possible forum, ${ }^{101}$ has reportedly refused to prosecute pirates to prevent reprisals against its nationals and vessels. ${ }^{102}$ The limitations of national prosecutions have led some states to call for the creation of a specialized international court, though such action seems far off. ${ }^{103}$

III

\section{LEgAL OBSTACLES TO FIGHTING PIRACY}

While international law has developed to include many new crimes, the successful prosecution of piracy has grown more difficult than it was in the age when ships were powered by sails. Although international law obligates nations to repress piracy, many legal rules, practical constraints, and other considerations pull states in the opposite direction. These tensions involve conflicts between older rules designed to promote international security and newer ones aimed at protecting individuals from abuse by state authority. While some of the legal problems discussed here are hypothetical, they can have a real chilling effect on actions by American and other Western officials. ${ }^{104}$

99. Celestine Achieng, U.S. Navy Hands over 17 Pirates to Kenya, Reuters, June 10, 2009, available at http://www.reuters.com/article/africaCrisis/idUSLA1052558 (reporting on tensions with Kenyan Muslims caused by the prosecutions).

100. Barney Jopson, Kenya Signs Deal to Prosecute Somali Pirates, Fin. Times, Dec. 12, 2008, available at http://www.ft.com/cms/s/0/9b63b8e6-c7c4-11dd-b611-000077b07658.html? nclick_check=1.

101. Elizabeth Pineau, France Asks Seychelles to Help with Pirate Trials, Reuters, Oct. 18, 2009, available at http://www.reuters.com/article/africaCrisis/idUSLI622681.

102. Kim Sengupta, Is Seychelles Turning a Blind Eye to Pirates?, Oct. 28, 2009, IndePendent (London), at 2; J.E. Dyer, They Sell Pirates in the Seychelles, Contentions, http://www.commentarymagazine.com/blogs/index.php/j-e-dyer/139812.

103. See S.C. Res. 1851 Press Release, supra note 15 (statement of Danish Ambassador Carston Staur); id. (statement of U.S. Sec'y of State Condoleezza Rice); Frank Gardner, How Do You Tackle Piracy?, BBC News, Dec. 13, 2008, http://news.bbc.co.uk/2/hi/africa/7782016.stm (reporting that U.S. and French officers at a conference on piracy called for creation of international court and prison for pirates); Germany Calls for International Court to Prosecute Pirates, FoxNews.com, Dec. 23, 2008, http://www.foxnews.com/story/0,2933,471804,00.html; David Osler, Russia Calls for a Piracy Court, Lloyd's List, May 14, 2009, http://www.lloydslistdcn.com.au/archive/2009/may/weekly-edition-14th-of-may-2009/russiacalls-for-a-piracy-court.

104. Currently, several former Bush administration officials face threats of prosecution for their decisions surrounding the classification and treatment of suspected terrorist detainees. See, e.g., Mark Benjamin, How to Build A Torture Commission, Salon.com, Mar. 4, 2009, http://www.salon.com/news/feature/2009/03/04/torture_commission/index.html; Editorial, A Truth Commission for the Bush Era?, N.Y. TImes, Mar. 2, 2009, at A12; Bobby Ghosh, Leahy's Plan to Probe Bush-Era Wrongdoings, Time.coM, Feb. 17, 2009, http://www.time.com/time/ nation/article/0,8599,1879810,00.html. Their successors in office may be reluctant to take actions that redound principally to the benefit of international shipping if there is even a small chance that they may later be held criminally liable. 


\section{A. Pirates as Civilians}

Modern international law precludes the classic and most obvious antipiracy measure: killing them. Under the classic law of nations, pirates were simultaneously criminals and military targets. They were hostis humani generis - enemies of all mankind - in the military sense, as well as offenders of international law. ${ }^{105}$ They had the disabilities of both combatants and criminals, without the privileges or immunities of either class. They could be tried when captured, unlike regular combatants, but if encountered on the high seas, they could be attacked and slain. ${ }^{106}$ Moreover, international law recognized that returning pirates to port for trial could be extremely burdensome, and thus it permitted summary shipboard proceedings and executions. ${ }^{107}$ In short, pirates had a status much like unlawful combatants: they could be dealt with either militarily or criminally at the enforcing state's convenience.

Under modern international law, the situation is reversed. By the 1930s, Western lawyers declared that anything short of a full trial or court martial was "inconsistent with the spirit of modern jurisprudence." ${ }^{\text {"108 }}$ Moreover, pirates are considered civilians. ${ }^{109}$ Modern human rights and humanitarian law prohibits extrajudicial killing of civilians except in self-defense. ${ }^{110}$ UNCLOS, a codification of the modern law of the high seas, stipulates that the criminal justice system is the only way of dealing with pirates. ${ }^{111}$ So, except in situations of immediate self-defense, naval forces are prohibited from killing pirates and must instead seek to apprehend them.

Given that pirates are civilians on board civilian vessels, patrolling navies can do little until the suspects attempt to board another ship. International law does not criminalize being on a Somali fishing vessel, even if the only pieces of "fishing equipment" on board are AK-47s and RPGs. Consequently, navies

105. See CoKe, supra note 61, at 113; OppenheIm, supra note 61, § 272, at 325-26 (1905).

106. 4 William Blackstone, Commentaries on the Laws of England 71 (1838) (“As therefore he has renounced all the benefits of society and government, and has reduced himself to the savage state of nature, by declaring war against all mankind, all mankind must declare war against him[.]"); OPPENHEIM, supra note 61, § 278, at 330 .

107. See OpPenheim, supra note 61, § 278, at 330.

108. See Harvard Draft Convention, supra note 73, at 853 (disagreeing with support for summary proceedings expressed in draft report by League of Nations committee of experts). ๆ 40 .

109. See Treves, supra note 74, at 412-13; NATO Parliamentary Assembly, supra note 89,

110. See Geneva Convention Relative to the Treatment of Prisoners of War art. 3(1) (Third Geneva Convention), Aug. 12, 1949, 75 U.N.T.S. 135, 136 [hereinafter Common Article 2]; Protocol Additional to the Geneva Conventions of 12 August 1949, and Relating to the Protection of Victims of Non-International Armed Conflicts art. 13 (Protocol II), June 8, 1977, 1125 U.N.T.S. 609 (banning attacks on civilians); see also International Covenant on Civil and Political Rights art. 6(1)-(2), Mar. 23, 1976, 999 U.N.T.S. 171 (prohibiting extrajudicial killing). While the Geneva Conventions do not necessarily apply to conflicts with pirates on the high seas, the minimal obligations of Common Article 3 are widely thought to be generally applicable to all uses of military force as a matter of customary law.

111. See UNCLOS, supra note 8, art. 105. 
must stop pirates in the narrow window when they speed toward a vessel and have not yet taken the ship and its crew hostage. Once the pirates control a vessel, responding nations and owners face overwhelming pressure to negotiate with them.

The U.N. Security Council has expanded military avenues for combating pirates, demonstrating that nations no longer regard the purely criminal approach to piracy as satisfactory. The United States has won Security Council approval for airstrikes of the kind it controversially uses against alleged terrorists in Yemen, Pakistan, and Sudan. ${ }^{112}$ However, the Security Council resolution requires that military action comport with international law. ${ }^{113}$ This suggests that the resolution either does very little or that international humanitarian law allows for targeted killings. Notably, the U.N. Security Council opened the door to such action despite the harsh criticism of targeted killings from the United Nations and human rights groups in nonpiracy contexts, like terrorism. ${ }^{114}$

Forcefully dealing with pirates creates a serious risk that responding nations will be accused of violating international humanitarian law. Attacking pirate vessels on the high seas could open nations to accusations of illegal "targeted killings" of civilians. ${ }^{115}$ In recent years international lawyers and nongovernmental organizations have increasingly scrutinized tactical military decisions for proportionality and other indicia of legality. ${ }^{116}$ In wars against nonuniformed combatants and terrorist groups (so-called nonstate irregulars), national forces have been accused of violating humanitarian law for not successfully distinguishing between combatants and civilians in environments where the former freely commingle with the latter. ${ }^{117}$ Such considerations have undoubtedly deterred nations from using the Security Council authorization to attack Somali pirates on land. Indeed, an American admiral in the Gulf of Aden criticized the Security Council resolution as being likely to cause high civilian casualties given the difficulty of distinguishing pirates from anyone else. ${ }^{118}$

112. See supra note 43 and accompanying text; S.C. Res. 1851, U.N. Doc. S/RES/1851, ๆ 6 (Dec. 16, 2008).

113. Id.

114. Such charges have plagued the United States and Israel in their campaigns against terrorists. See, e.g., Laura Blumenfeld, In Israel, A Divisive Struggle over Targeted Killing, Wash. Post, Aug. 27, 2006, at A1.

115. Id.

116. See, e.g., B'Tselem, Attacks on Israeli Civilians by Palestinians: Israel's Obligations in Responding to Rocket and Mortar Fire, http://www.btselem.org/english/Israeli_Civilians/ Israels_obligations.asp (last visited Jan. 20, 2010).

117. See id.

118. Lolita C. Baldor \& Anne Gearan, Navy Commander Questions Land Attacks on Pirates, Assoc. Press, Dec. 13, 2008, available at http://abcnews.go.com/Politics/ wireStory?id=6454447; see also Frank Gardner, How Do You Tackle Piracy?, BBC News, Dec. 13, 2008, http://news.bbc.co.uk/2/hi/africa/7782016.stm (The United States "did not yet have enough intelligence on which individuals were involved to go after them without causing civilian casualties”). 
Such concerns have proven warranted. In November 2008, India reported that one of its frigates had sunk a pirate mother ship in the Gulf of Aden. News soon emerged that the vessel was in fact a Thai fishing trawler that had been captured by pirates; only one of the sixteen crewmembers survived. ${ }^{119}$

\section{B. Pirates as Combatants}

Given that combat operations against pirates are unlikely, judicial remedies are seemingly the most promising alternative. Yet, as the next two Parts describe, numerous obstacles stand in the way. Although pirates have not been treated as combatants under the UNCLOS regime, Somali pirates could perhaps claim combatant status with its attendant Geneva Convention protections, especially in light of developments in international humanitarian law over the past decade in relation to nonstate irregulars. Thus, the status of pirates under the Conventions poses many of the same problems faced in dealing with al Qaeda and other international terrorist organizations. The goal here is not to defend the merits of such a characterization. Rather, it is to show that there are arguments available to the pirates similar to those that have been taken seriously in the context of al Qaeda detainees. Even if these legal claims are ultimately not viable, their mere assertion by suspected pirates would impede prosecution and increase the costs of detention. Thus, these issues may help explain the lack of Western prosecution.

Both al Qaeda and the pirates engage in organized armed attacks, often within the context of a broader conflict-like Afghanistan, for example. Yet they do not fall naturally within the basic parameters of the Third Geneva Convention Relative to the Treatment of Prisoners of War, which contemplates traditional armies and well-organized militia forces. ${ }^{120}$ The drafters of the Conventions had in mind neither large-scale international terrorism, which had not developed at the time, nor large-scale piracy, which was thought to be a thing of the past. ${ }^{121}$

Article 4(a)(2) of the Third Geneva Convention does recognize the role of irregular "militias," "organized resistance movements," and "other volunteer corps" so long as they abide by the laws of war and conduct themselves like a traditional military organization. ${ }^{122}$ In the absence of these conditions, the Bush administration declared al Qaeda beyond the protections of the Third Geneva Convention. The response to that decision, perhaps the most widely criticized international legal action of the past decade, ${ }^{123}$ suggests denying POW status to

119. See Mark McDonald, Ship Sunk by Indian Navy Had Been Hijacked that Day, INT'L Herald Tribune, Nov. 27, 2008, at 2 (reporting that India claimed the frigate had been fired on by the pirates aboard the trawler).

120. See Third Geneva Convention, supra note 110, 75 U.N.T.S. at 135.

121. See Harvard Draft Convention, supra note 108, at 764 (observing that current international law on piracy is "of little value" because "large scale piracy disappeared long ago").

122. See Third Geneva Convention art. 4(a)(2), supra note 110, 75 U.N.T.S. at 138.

123. See, e.g., David Glazier, A Self-Inflicted Wound: A Half-Dozen Years of Turmoil over 
pirates would not be simple. Moreover, the United States previously extended Geneva Convention protections to pirates without conceding that they were legally entitled to them. ${ }^{124}$

Pirates satisfy the Article 4 requirements better than al Qaeda does. Pirates have some local command structure, evidenced by the participation of dozens of men in complicated seizures and their ability to divide large amounts of ransom peaceably. ${ }^{125}$ Indeed, unlike ordinary criminal groups, they even have spokesmen. ${ }^{126}$ Pirates carry arms openly, as the Geneva Convention requires of militias, resistance movements, and other non-national forces. ${ }^{127}$ And while they do not observe all the rules and customs of war, they often treat captured crews reasonably, providing a basis for the argument that they would abide by the rules of reciprocity. Few would argue that Article 4 requires perfect observance of the laws of war for Geneva protections to apply. ${ }^{128}$ Such a standard would make the Article a dead letter.

A broader question is whether pirates can be considered militias or other organized resistance movements, and not just bandits. The situation in Somalia is even more chaotic than Afghanistan in 2001. Because many Somali pirates are based out of one of the two de facto independent provinces that have peeled away from Somalia, it is very difficult to determine who, if anyone, falls under Article 4's definition of POWs. ${ }^{129}$

Furthermore, some pirates have claimed a political purpose: to drive away foreign vessels that have intruded on Somali fishing grounds and dumped poisonous waste. ${ }^{130}$ Normally the Somali navy would do this, but it no longer exists. ${ }^{131}$ This account has an element of truth. When the Somali government collapsed in 1991, commercial fishing fleets from around the world plundered Somalia's tuna-rich waters. ${ }^{132}$ Pirates often cite France and Spain as the worst

the Guantánamo Military Commissions, 12 LewIS \& Clark L. Rev. 131 (2008); Stephen I. Vladeck, Congress, the Commander-in-Chief, and the Separation of Powers After Hamdan, 16 Transnat'l L. \& Contemp. Probs. 933, 951 (2007).

124. See Bahar, supra note 91, at 36, 45-46 (2007) ("In the case of Somalia today . . . captured pirates would, and should, receive Geneva Conventions treatment, but they should also remain eligible for prosecution.”).

125. See Gettleman, supra note 13.

126. Id.

127. See Third Geneva Convention art. 4(A)(2)(c), supra note 110, 75 U.N.T.S. at 138 (affording POW status on basis of abiding by this and other conditions); Michael H. Passman, Protections Afforded to Captured Pirates Under the Law of War and International Law, 33 TuL. MAR. L.J. 1, 24 (2008).

128. See Third Geneva Convention art. 4(A)(2)(d), supra note 110, 75 U.N.T.S. at 138.

129. See id. art. 4(A)(1) (discussing armed forces of a Party to the conflict).

130. Najad Abdullahi, 'Toxic Waste' Behind Somali Piracy, AlJazeEra.net, Oct. 11, 2008, http://english.aljazeera.net/news/africa/2008/10/2008109174223218644.html.

131. Alisha Ryu, Analysts Skeptical New Somali Navy Can Fight Piracy, Voice of AMERICA, June 18, 2009, available at http://www.voanews.com/english/archive/2009-06/2009-0618-voa34.cfm?CFID=277283664\&CFTOKEN=40212391\&jsessionid=88309d93b2488c23b9fae 4512d2d6f47424a.

132. Gettleman, supra note 13. 
offenders when it comes to toxic waste dumping and illegal fishing. ${ }^{133}$ Of course, the pirates have not limited their attacks to fishing or dumping; indeed, they largely attack freighters. And they demand money, not political changes.

Yet their pretensions have received some international support. Muammar al-Gaddafi, the Libyan leader whose nation headed the African Union at the time, defended the idea of pirates as freedom fighters: "It is a response to greedy Western nations, who invade and exploit Somalia's water resources illegally .... It is not a piracy, it is self defence [sic]. It is defending the Somalia children's food." 134 In this version, pirates sound a little bit like "[i]nhabitants of non-occupied territory, who on the approach of the enemy spontaneously take up arms to resist the invading force, without having had time to form themselves into regular armed units," who can enjoy POW protections under the Third Geneva Convention. ${ }^{135}$ Indeed, as Western efforts against the pirates increase one might expect to hear more such self-defense claims.

Apart from issues concerning the pirates' status as combatants, there are major preliminary doubts about whether the Geneva Conventions apply to the Gulf of Aden situation at all, in particular whether the crisis in the region qualifies as an "armed conflict between . . . High Contracting Parties."136 Armed conflict is distinguished from "isolated and sporadic acts of violence"137 and "banditry."138 There is a strong argument that an international armed conflict exists in Somalia. Ethiopia, with the backing of the United States, invaded Somalia in 2006 to overthrow an Islamicist movement and install a transitional government. ${ }^{139}$ Ethiopian troops withdrew in January 2009, leaving behind a contingent of African Union peacekeepers, who have been caught up in bloody three-way fighting that shows no signs of stopping. ${ }^{140}$

Even if an armed conflict exists in Somalia, it is not clear that it extends outside of Somali waters and into the high seas. Also, pirates captured by nations patrolling international waters may not have "fallen into the power of the enemy" within the meaning of Article $4 .{ }^{141}$ The uncertainty about the scope of the armed conflict seems, if anything, less acute than similar questions raised

133. See French, Spanish Defence Ministers Launch Anti-Piracy Plan, Agence FrancePresse, Nov. 2, 2008, http://www.eubusiness.com/news-eu/1225635422.48.

134. Argaw Ashine, Gaddafi Defends Somali Pirates, Daily Nation (Kenya), Feb. 5, 2009, available at http://www.nation.co.ke/News/africa/-/1066/525348/-/view/printVersion//wjo0r1z/-/index.html.

135. See Third Geneva Convention art. 4(A)(6), supra note 110, 75 U.N.T.S. at 140.

136. See Common Article 2, supra note 110.

137. Protocol II, supra note 110, 1125 U.N.T.S. at 609

138. Prosecutor v. Tadic, Trial Judgment, Case No. IT-94-1-I ICTY (May 7, 1997).

139. See Int'l Law Ass'n, Draft Report on Meaning of Armed Conflict in INTERNATIONAL LAW (2008) (disputing British court decision treating Somalia as a noninternational armed conflict).

140. Mohammed Ibrahim, Somalia Fighting Kills at Least 15, N.Y. Times, Feb. 25, 2009, at A6.

141. See Third Geneva Convention art. 4, supra note 110, 75 U.N.T.S. at 140. 
by the capture of alleged Islamic terrorists held by the United States. They were seized in a variety of countries, often far away from any fighting. ${ }^{142}$ Thus, while Article 4's conditions may not be strictly satisfied, countries may still feel the need to afford at least some Geneva protections to captured pirates.

Crucially, the Geneva Conventions apply in situations of uncertainty. Article 5 provides that when there is "doubt" about whether a person captured committing a "belligerent act" is entitled to POW status, such a person shall enjoy POW status "until such time as their status has been determined by a competent tribunal." 143 Thus, captured pirates could demand a hearing to assert their POW status, and in the meantime would have to be treated as POWs. ${ }^{144}$ Because POW status is an individualized and highly fact-specific inquiry, each pirate or group of pirates would likely require separate determinations. ${ }^{145}$ The Geneva Conventions do not specify the requirements for determining POW status. Consequently, United States courts have debated the issues extensively in dealing with Guantánamo detainees. Such tribunals would be faced with the novel legal and fact-specific issues about combatant status discussed above. While POW status would not prevent pirates from being prosecuted for attacks on civilian shipping, the added judicial procedures would increase the uncertainty and cost involved in apprehending pirates.

\section{Pirates as Defendants}

International law encourages international prosecution of pirates. ${ }^{146}$ However, some developments in international and Western legal norms make detention and prosecution difficult and potentially embarrassing for the forum state, much like the prosecutions of suspected terrorists. Difficulties center on establishing and proving who is a pirate. Unlike ordinary criminals, pirates are captured by military forces operating in the field. Moreover, pirates neither fly the Jolly Roger nor wear eye patches. Just as suspects detained by the United States might not actually be terrorists or unlawful combatants, similar misidentifications can occur when apprehending suspected pirates at sea. Furthermore, the judicial determination of pirate status places additional burdens on military forces.

Because there have been almost no prosecutions so far of pirates in domestic courts, it is difficult to assess the costs and obstacles involved in such efforts-though the unwillingness of nations even to try suggests the problems

142. See Charlie Savage, Obama's War on Terror May Resemble Bush's in Some Areas, N.Y. Times, Feb. 18, 2009, at A20; see also Mark Mazzetti \& Eric Schmitt, Military Sending Foreign Fighters to Home Nations, N.Y. TIMEs, Aug. 28, 2008, at A1.

143. See Third Geneva Convention art. 6, supra note 110, 75 U.N.T.S. at 142.

144. Id. art. 5 and Commentary, supra note 110, 75 U.N.T.S. at 140-42.

145. George Aldrich, The Taliban, al Qaeda, and the Determination of Illegal Combatants, 96 Am. J. INT'L L. 891, 896-97 (2002).

146. See UNCLOS, supra note 8 , arts. 100-07. 
are significant. ${ }^{147}$ Several precedents show some of the likely obstacles. In 2006, U.S. warships captured Somali pirates and turned them over to Kenya for trial. ${ }^{148}$ The U.S. Navy Judge Advocate General (JAG) officer who coordinated the 2006 prosecution has described it in great detail. ${ }^{149}$ Kenya also took custody of over 100 pirates captured by the United States and other countries between 2008 and 2009. ${ }^{150}$ Additionally, the United States has convicted a foreign national under SUA for crimes against a foreign vessel. ${ }^{151}$ While the case itself was of little international importance, ${ }^{152}$ the extraordinary measures taken to prosecute a single defendant show why nations have not been interested in prosecuting pirates. The following subsections discuss three of the largest hurdles to domestic prosecution of pirates: (1) proving "pirate" status, (2) the costs of trial, and (3) the potential embarrassments in detaining suspects.

\section{Status as Pirates}

Universal jurisdiction applies only to pirates. Captured Somalis insist in court that they are not pirates but rather simple fishermen, erroneously seized by a foreign navy. ${ }^{153}$ Because many pirates are in fact fishermen, their claim is actually somewhat plausible. ${ }^{154}$ Piracy is not a full-time job. ${ }^{155}$ Simply having weapons on a boat would not distinguish the pirates from many other seafarers near Somalia. Furthermore, establishing the identity or even nationality of captured individuals will be difficult, as they are unlikely to possess identification. ${ }^{156}$

147. The same can be said about using civilian courts for Guantánamo detainees, a development currently in its infancy.

148. Press Release, U.S. Embassy to Kenya, Capture of Suspected Somali Pirates, Feb. 2, 2006, http://nairobi.usembassy.gov/pr_20060202.html.

149. See Bahar, supra note 91, at 41.

150. Sarah McGregor, Aid Group to Defend Somali Piracy Suspects, Ensure Fair Trials, BloOMBERG, Aug. 3, 2009, http://www.bloomberg.com/apps/news?pid=20601116\&sid =a5wQ7mzHZEEY; Sarah McGregor, Somali Pirates' Kenya Trial, Bloomberg, Aug. 7, 2009, http://www.bloomberg.com/apps/news?pid=20601116\&sid=aL9GurP5q2uc.

151. See United States v. Shi, 525 F.3d 709 (9th Cir. 2008); see also Kontorovich, supra note 83 .

152. The case concerned the murder of a fishing trawler captain by the disgruntled ship's cook. See id.

153. Bahar, supra note 91, at 48; David McKenzie, Somali Men Accused of Piracy Face January Trial, CNN.coM, Dec. 11, 2008, http://www.cnn.com/2008/WORLD/africa/12/11/ kenya.piracytrial/index.html (quoting lawyer for suspected pirates captured by Britain and turned over to Kenya as arguing that his clients were fishing in Yemeni waters); Katharine Houreld, Suspected Somali Pirates Appear in Kenyan Court, ABC News, Apr. 23, 2009, http://abcnews.go.com/International/wireStory?id=7407910.

154. See Jeffrey Gettleman, Somalia Pirates Capture Tanks and Global Notice, N.Y. Times, Sept. 27, 2008, at A1.

155. Suspected Pirates Face Trial, Kenya Broad. Corp., Dec. 11, 2008, http://www.kbc.co.ke/story.asp?ID=54420.

156. See Travis Kavulla, Prosecuting Captured Somali Pirates Poses Challenges, FoxNews.com, Nov. 26, 2008, http://www.foxnews.com/story/0,2933,457827,00.html. 
Such challenges must be taken seriously, because the alternative is the detention of innocent civilians. ${ }^{157}$ To be sure, treating the detainees as innocent fishermen would require giving credence to some dubious factual claims. ${ }^{158}$ However, the same is true of many Guantánamo detainees captured in Afghanistan and elsewhere. ${ }^{159}$ They have claimed that they were innocent passersby, ${ }^{160}$ aid workers, ${ }^{161}$ tourists, ${ }^{162}$ minors, ${ }^{163}$ or simply ignorant of the nature and aims of the organization for which they worked. ${ }^{164}$ Regardless of their plausibility, these claims won significant sympathy for the detainees. Moreover, U.S. courts have held that because the power to detain depends on the foreigner's status as a combatant, detainees can appear before tribunals to challenge the factual basis for being classified as a combatant even before a full trial for their alleged crimes. ${ }^{165}$

In short, there are real difficulties in bringing a criminal case against armed foreigners seized in remote parts of the world. Evidentiary problems have already forced the U.S. Navy to release many of the pirates it seized in the wake of its January 2009 agreement with Kenya. ${ }^{166}$ Even though they were caught in response to a distress call from a commercial vessel, the evidence was "not ironclad." ${ }^{167}$ Other nations also release pirates at a high rate because of

157. See Hamdi v. Rumsfeld, 542 U.S. 507, 526-27 (2004) (holding that the legal status of a detainee captured in Afghanistan is not "undisputed" where the detainee claims he is not a combatant).

158. Matthias Gebauer \& Holger Stark, Somali Pirate Trial Tests Limits of EU Mission, Der SpIEgel, Apr. 1, 2009, http://www.spiegel.de/international/world/0,1518,616760,00.html ("There are many indications that the [pirate] suspects' testimony [that they knew nothing of the nature of their boat's mission] is nothing but lies to cover themselves, but proving the contrary could be complicated.”).

159. See, e.g., In re Guantanamo Detainee Cases, 355 F. Supp. 3d 443 (D.D.C. 2005); Khalid v. Bush, 355 F. Supp. 2d 311 (D.D.C. 2005).

160. Rasul v. Bush, 215 F. Supp. 2d 55, 59-61 (2002) (describing factual claims of detainees).

161. See Hamdi, 542 U.S. at 511.

162. See Dep't of Defense, Office of Admin. Review of Detention of Enemy Combatants at U.S. Naval Base Guantanamo Bay, Unclassified Summary of Evidence for Administrative Review Board in the Case of Lagha, Lufti Bin Swei, May 2, 2005, at 3, available at http://projects.nytimes.com/guantanamo/detainees/660-lufti-bin-swei-lagha/documents/1/pages/ 1089?scp=3\&sq=lagha\&st=cse\#4 ("The following primary factors favor release or transfer: (a) Detainee stated that he went to Afghanistan as a tourist. (b) During his stay in Afghanistan, the detainee said that he spent his time fishing and recreating, and remained in Jalabad the entire time.”).

163. Carol Rosenberg, Bring Guantanamo Detainee Back Now, Canadian Court Says, Sun-Sentinel, Aug. 15, 2009, at 16A.

164. See, e.g., William Glaberson \& Eric Lichtblau, Guantánamo Detainee’s Trial Opens, Ending a Seven-Year Legal Tangle, N.Y. Times, July 22, 2008, at A12.

165. See Rasul v. Bush, 542 U.S. 466 (2004).

166. Sandra Jontz, 9 Suspected Pirates Freed in Somalia, Stars \& Stripes, Mar. 4, 2009, available at http://www.stripes.com/article.asp?section=104\&article=61100; see also Questions About Evidence Against Suspected Pirates, Int'L Herald TriB., Feb. 13, 2009, available at http://www.iht.com/articles/ap/2009/02/13/america/US-Pirates.php.

167. See Kate Wiltrout, Nine Suspected Pirates Set Free; Others Could Face Trials, VA.- 
such concerns.

\section{Burdens of Trial}

Ensuring that suspected pirates have the normal rights of a defendant in a civilian trial would be particularly difficult given the remote location and nature of the alleged crime. Military personnel have little training in preservation and collection of evidence. For example, in the case of suspected pirates captured by a German warship, the captain ordered their skiff sunk and weapons dumped into the sea for security reasons, complicating the subsequent Kenyan prosecution. ${ }^{168}$ Transporting the prosecution, defendants, witnesses, and evidence to a foreign court would be burdensome and impede ongoing interdiction efforts. ${ }^{169}$ Identification by victims can be difficult, as the multinational crews of foreign-flagged vessels would have to be either detained or returned from their homes around the world. Otherwise, by the time the trial starts, the crew may be scattered around the world and simply unavailable. ${ }^{170}$ For example, in the one SUA prosecution on record, the Shi case, the vessel was brought into a U.S. port and the entire crew held for months as material witnesses. ${ }^{171}$ Yet this is not a feasible solution for Somali piracy, because detaining crews would keep their vessels from continuing their voyages, paralyzing international commerce as much or more than the underlying piracy.

Adding to the problem, domestic courts struggle to provide counsel and translation services in the defendants' Somali dialect, even in neighboring Kenya. ${ }^{172}$ Providing translation services for testifying witnesses is also problematic, further complicated by the fact that they often hail from a variety

Pilot, Mar. 3, 2009, available at http://hamptonroads.com/2009/03/nine-suspected-pirates-setfree-others-could-face-trials.

168. Gebauer \& Stark, supra note 158.

169. Baumgartner Statement, supra note 54 (citing the "significant legal and logistical challenges in transporting pirates, evidence and witnesses to appear in their courts" as a reason patrolling navies do not take custody of pirates); James Kraska \& Brian Wilson, Fighting Pirates: The Pen and the Sword, World PoL'y J., Winter 2008-09, at 45 (noting the "great expense and logistical and legal burdens of transporting the pirates to a Western country for prosecution").

170. See Joint UNDOC/Eur. Comm'n Program, EU Support to the Trial and Related Treatment of Piracy Suspects 3, 10 (May 2009) [hereinafter "EU Support"], available at http://www.asil.org/files/AnnexE-ECAssistance.pdf (discussing obstacles to prosecuting pirates, and noting that "locating [witnesses] and transferring them to the trying state can be difficult, expensive, and time consuming”). See, e.g., Gebauer \& Stark, supra note 158 (reporting that the trial of a group of pirates in Kenya may be dismissed if the judge requires testimony of the captain of the victim vessel, who is outside the jurisdiction of the prosecuting state).

171. See United States v. Shi, 396 F. Supp. 2d 1132, 1134 (D. Haw. 2003) (noting in a prosecution under SUA that the case required arresting the entire crew of the victim vessel and holding them without bail as material witnesses, measures which were only possible because the ship had been taken into U.S. waters by the Coast Guard).

172. See Kavulla, supra note 156; Kenyan Pirates Trial Delayed, News24.com, http://www.news24.com/Content/Africa/News/965/adaf2865499c43b986ce83300c40087e/06-022006-11-01/Kenyan_pirates_trial_delayed. 
[Vol. 98:243

of distant countries. ${ }^{173}$ For example, in the Shi case, the United States obtained Mandarin translators for the entire crew of the victim vessel. ${ }^{174}$ Furthermore, naval officers in active service would be called upon repeatedly to testify, as the case would depend largely on the accounts of those present during the arrest of pirates. ${ }^{175}$ Given that such trials can take months, this would in effect require a dedicated cadre of officers. ${ }^{176}$

\section{Allegations of Abuse}

Kenyan prisons are at best grossly overcrowded and vermin infested. ${ }^{177}$ In the two cases brought in Kenyan courts so far at the behest of Western powers, the defendants alleged that they were tortured and denied religious privileges by their captors. ${ }^{178}$ Given that most Somalis are Muslim, there is always a danger that some elements might seize upon such allegations to incite antiWestern sentiment like they did regarding incidents in Guantánamo where U.S. guards allegedly desecrated the Koran. ${ }^{179}$ Given the allegations of the Kenyan prisoners, it appears that some pirates are taking a page from the Guantánamo detainees' playbook. ${ }^{180}$ Muslim leaders in Kenya have already likened the piracy prosecutions there to the War on Terror as another "pretext" for the government to "further engage in the human rights violation of Muslims."181 One can expect that if prosecution becomes more regular, claims of abuse will increase. Human rights groups have already started to raise these concerns. Recently, Ben Rawlence of Human Rights Watch said of the agreement with Kenya: "There is a very real risk that this agreement might be perceived as an attack on Muslims. Anything that the United States does is subject to a high

173. EU SUPPORT, supra note 170, at 11 .

174. Brief of Plaintiff-Appellee at 3, United States v. Shi, 525 F.3d 709 (9th Cir. 2008) (No. 06-10389), 2007 WL 1511823.

175. Id. at 10-11; EU SUPPORT, supra note 170, at 3.

176. Similarly, one of the major concerns about civilian trials for Guantánamo detainees is the extent to which military personnel would have to come and testify. Compare Hamdi, 542 U.S. at 534-35 ("[A]rguments that military officers ought not have to wage war under the threat of litigation lose much of their steam when factual disputes at enemy-combatant hearings are limited to the alleged combatant's acts."), with id. at 595-96 (Thomas, J., dissenting) ("Under the process envisioned by the plurality, various military officials will have to take time to litigate [combatant status] matter[s].”). The problems of prosecuting piracy show that concerns about diverting or distracting military personnel through the judicial process for those detained by them are not fanciful.

177. Gebauer \& Stark, supra note 158 .

178. See Bahar, supra note 91, at 41; Politics Influences the Jurisdiction for Somali Pirate Trials, Deutsche Welle, Apr. 22, 2009, http://www.dw-world.de/dw/article/0,,4198300,00.html (reporting allegations that detainees were denied an Islamic diet by Kenya).

179. See Richard A. Serrano \& John Daniszewski, Dozens Have Alleged Koran's Mishandling, L.A. TIMES, May 22, 2005, at A1.

180. See Bahar, supra note 91, at 41.

181. Kenya: Concerns Growing over Trial of Pirates in Kenya, MusLIm News, June 16, 2009, http://www.muslimnews.co.uk/news/news.php?article=16363. 
degree of suspicion.”182 Notwithstanding the truth of these allegations, they have negative consequences for detaining and capturing states.

\section{Pirates as Refugees}

Other human rights rules of Western countries increase the cost of arresting pirates to the apprehending nation, while decreasing the cost to the pirates themselves. For example, Britain reportedly instructed its ships not to capture pirates they encountered because they could claim asylum under EU human rights law once on board a British vessel, and certainly if brought to Britain for trial. ${ }^{183}$ Suspected pirates could quite plausibly claim that they would be subject to unfair trials, torture, and extrajudicial killing if they are repatriated to Somalia, where law and order have largely collapsed. Thus, they might be able to stay in a prosecuting country indefinitely if acquitted or upon their eventual release from prison. Obtaining residency in a Western nation would undoubtedly be seen as a benefit for most Somalis. ${ }^{184}$ Such "rewards" would only exacerbate the piracy problem. ${ }^{185}$ Any nation that has ratified the European Convention on Human Rights would have similar concerns. The United States is also a party to treaties that require granting asylum under certain circumstances, but the protections are not as broad as under European law. ${ }^{186}$

\section{E. Problems with Trial in Other Countries}

With none of the capturing countries wishing to prosecute under universal jurisdiction in their own courts, the only alternative to setting pirates free is transferring them to another country. Several states have taken this course, despite difficulties in finding a willing recipient state. Such renditions raise legal problems themselves.

\section{Nonrefoulement}

The most obvious nation to transfer captured Somali pirates to would be Somalia. Yet most countries do not see this as an option, both because of the lack of a functioning central government and the significant probability that the

182. Alisha Ryu, Rights Group Questions US Deal to Send Pirates to Kenya, VoICE OF AMERICA, Feb. 13, 2008, http://www.voanews.com/english/2009-02-13-voa43.cfm.

183. Woolf, supra note 11.

184. Somali Pirates on Trial in Netherlands, DutchNews.nL, May 18 2009, http://www.dutchnews.nl/news/archives/2009/05/somali_pirates_on_trial_in_net.php (reporting that pirates on trial in Holland are happy to be there and wish to stay).

185. See Suspected Pirates Turned over to Yemen, CNN.com, Dec. 5, 2008, http://www.cnn.com/2008/WORLD/africa/12/05/yemen.pirates/index.html; Derek S. Reveron, Think Again: Pirates, ForeIgN PoL'y, Jan. 2009, available at http://www.foreignpolicy.com/ story/cms.php?story_id=4626\&page $=1$.

186. Aoife Duffy, Expulsion to Face Torture? Non-Refoulement in International Law, 20 INT'L J. REFUGEE L. 373, 378-79. 
transferee would be subject to unfair trials, cruel treatment, and the death penalty. ${ }^{187}$ Some European governments have expressed concern that repatriation would conflict with the sending state's obligation of nonrefoulement under various international treaties. ${ }^{188}$ Nonrefoulement prohibits sending people to countries where they will likely be abused. ${ }^{189}$ The scope of this norm has been a major subject of debate in recent years regarding Guantánamo detainees, since terrorists, like pirates, often come from countries with deplorable human rights records. Yet France, one of the more active nations in the piracy campaign, regularly resorts to repatriation of pirates to Somalia, relying on assurances that they will not be tortured. ${ }^{190}$ Similarly, Denmark and Russia have handed over suspects to Yemen, another country with a terrible human rights record. ${ }^{191}$

The United States and Europe have pursued another avenue-transferring suspected pirates to neighboring Kenya. ${ }^{192}$ While the alleged pirates have no connection to Kenya, they could be prosecuted there under universal jurisdiction. The advantages of such an arrangement for the sending states are obvious. Trials in Kenya proceed without the expansive protections of the European Convention on Human Rights or the U.S. Constitution, and would free the senders from some of the difficulties discussed in this Essay. The proceedings are relatively speedy and informal. ${ }^{193}$

It is less obvious how Kenya benefits from such an arrangement. There appear to be implicit financial benefits. The EU, along with a U.N. agency, has

187. See, e.g., Woolf, supra note 11.

188. See EU Launches Anti-Piracy Mission off Somalia, E.U. ObSERVer.com, Nov. 10, 2008, http://euobserver.com/9/27248; Corey Flintoff, Prosecuting Pirates: No More Walking the Plank, NAT'L PUB. RADIO, Jan. 9, 2009, http://www.npr.org/templates/story/ story.php?storyId=99169738; Woolf, supra note 11 ("The [British] Foreign Office has advised that pirates sent back to Somalia could have their human rights breached because, under Islamic law, they face beheading for murder or having a hand chopped off for theft.”).

189. See U.N. Convention Against Torture and Other Cruel, Inhuman or Degrading Treatment or Punishment art. 3(1), G.A. Res. 39/46, 39 U.N. GAOR Supp. No. 51 at 197, U.N. Doc. A/RES/39/708 (1984), reprinted in 23 I.L.M. 1027 (1984) ("No State Party shall expel, return ('refouler') or extradite a person to another State where there are substantial grounds for believing that he would be in danger of being subjected to torture.").

190. See French Warship Thwarts Pirate Attack, Nat'L Pub. Radio, Jan. 6, 2009, http://www.npr.org/templates/story/story.php?storyId=99036159; Marcus Hand, French Navy Captures 19 Somali Pirates, LloyD's List, Jan. 5, 2009, available at http://www.lloydslist.com/ 1l/news/french-navy-captures-19-somali-pirates/20017603853.htm. The European Court of Human Rights recently ruled that such assurances do not in themselves excuse refoulement. See Fiona de Londras, Saadi v. Italy: European Court of Human Rights Reasserts the Absolute Prohibition on Refoulement in Terrorism Extradition Cases, ASIL Insights, May 13, 2008, available at http://www.asil.org/insights080513.cfm\#_ednref3.

191. Russian Navy Transfers Detained Somali Pirates to Yemen, RIA Novosti, Feb. 18, 2009, available at http://en.rian.ru/world/20090218/120209688.html.

192. See Eugene Kontorovich, Introductory Note to Exchange of Letters Between European Union and Kenya to Prosecute Pirates, 48 InT'L Legal Materials 747 (2009).

193. For example, judges once brushed away Somali defendants' complaints of torture by observing that that "they do[] not appear to be bleeding." See Kavulla, supra note 156. 
agreed to a comprehensive program of judicial assistance to cover the cost of pirate prosecutions. ${ }^{194}$ The program covers everything from salaries and travel to office equipment, prison refurbishing, and other investments in the Kenyan criminal justice system. ${ }^{195}$ Denmark, which signed its own agreement with Nairobi, has also promised to compensate Kenya for the current financial cost of the trials. ${ }^{196}$ Such assistance may go beyond covering Kenya's actual costs. One might speculate that agreements with the United States contain similar understandings, or even promises of some kind of foreign aid. ${ }^{197}$

Thus, the Kenya trials may be an example of economic efficiency in international jurisdiction. ${ }^{198}$ With this jurisdictional arbitrage, the international community steers cases to the cheapest plausibly competent forum, while sharing the resulting surplus with that state. Indeed, the EU involvement contemplates so much bottom-up institution and capacity building, funded by foreign sponsors, that Kenyan courts are becoming de facto, ad hoc international piracy tribunals of the kind some have called for.

Turning Kenya into a clearinghouse for piracy trials also raises human rights concerns. While Kenya's legal system is superior to that of many of its neighbors, it still has a huge backlog of cases and rampant corruption. ${ }^{199}$ Shortly after the U.S. and EU piracy agreements were announced, the United Nations issued an extraordinary document calling for Kenya's police chief and attorney general to step down because of their complicity in the murders of hundreds of people. ${ }^{200}$ Even as the United States relied on Kenya to prosecute the pirates it had captured, Secretary of State Hillary Clinton criticized the country for failing to control "ongoing corruption, impunity, politically motivated violence, human-rights abuses and a lack of respect for the rule of law." ${ }^{201}$ The International Criminal Court has threatened to prosecute Kenyan leaders if the country does not establish a special tribunal to deal with the

194. EU SUPPORT, supra note 170, at 1-2.

195. See id. at 16 (listing EU budget for the program as $\$ 2.3$ million).

196. Kenya to Help Navy Chase Pirates, Copenhagen Post Online, Aug. 18, 2009, http://www.cphpost.dk/news/international/89-international/46605-kenya-to-help-navy-chasepirates.html.

197. See Gebauer \& Stark, supra note 158 ("In return [for taking pirates captured by European navies], the Kenyans hope to get speedboats, helicopters and modern fire trucks.”); see also Phillipe Naughton, Foreign Office Fury over Settlement of Guantanamo Uighurs in Bermuda, Times ONLINE (London), http://www.timesonline.co.uk/tol/news/world/article6480320.ece (reporting that Palau appeared to accept Guantánamo detainees in exchange for \$200 million in foreign aid, and that Bermuda was compensated for its costs in accepting detainees).

198. See generally Eugene Kontorovich, The Inefficiency of Universal Jurisdiction, 2008 U. ILl. L. Rev. 389, 398 (2008) (discussing role of implicit compensation paid from one state to another to facilitate efficient allocation of prosecutorial entitlements).

199. Sarah Childress, U.S. Warns Kenya on Human Rights, Aug. 6, 2009, at A7.

200. Derek Kilner, U.N. Official Calls for Dismissal of Kenya's Police Chief, Attorney General, Voice of AMericA, Feb. 25, 2009, http://www.voanews.com/english/2009-02-25voa59.cfm.

201. Sarah McGregor, Clinton Softens Stance on Kenyan Tribunal, Bloomberg, Aug. 5, 2009, http://www.bloomberg.com/apps/news?pid=20601116\&sid=aFTsF3Wq1K0c. 
[Vol. 98:243

bloody ethnic violence that occurred there in $2007 .{ }^{202}$ Much of the EU assistance to Kenya aims at ensuring trials and "detention conditions which meet international human rights standards. ${ }^{, 203}$ Yet the EU will presumably not provide indefinite oversight of Kenyan prisons throughout the pirates' incarceration. Thus, using Kenya as a go-to state for piracy prosecution suggests the United States and Europe will trade some prisoner security for convenience and expedience. Such tradeoffs proved highly controversial in the context of the War on Terror. ${ }^{204}$ It seems the Western public is not as concerned with such issues in relation to suspected pirates. ${ }^{205}$

\section{UNCLOS Article 105}

The Kenyan arrangement may be further complicated by an obscure clause in UNCLOS Article 105. Though the relevant language has never been judicially construed, ${ }^{206}$ it arguably casts doubt on the permissibility of universal jurisdiction by states other than the one that captured the pirates. The article, which codifies universal jurisdiction over piracy, provides that "every State may seize a pirate ship" on "the high seas, or in any other place outside the jurisdiction of any State.” While "every” state may seize pirates, Article 105 provides that the prosecution should be by "the courts of the state which carried out the seizure."207 The drafting history supports the reading that the article precludes transfers to third-party states. ${ }^{208}$

To be sure, the possibility of such transfers never occurred to the drafters, who thought large-scale high seas piracy a thing of the past. This underscores the uncertainties that arise when courts must fit new security challenges into international instruments that embody older paradigms. ${ }^{209}$ While Article 105 is

202. Id.

203. EU SUPPORT, supra note 170, at 3.

204. Amnesty International, Extraordinary Rendition, "Disappearances" and Secret Prisons, http://www.amnestyusa.org/war-on-terror/extraordinary-rendition-disappearances-andsecret-prisons/page.do?id=1051263 (last visited Mar. 11, 2009). In contrast, the rendition of terror suspects to Yemen, Egypt, and other countries is the subject of a long-running litigation against U.S. officials.

205. One obscure human rights group has challenged the transfer arrangements with Kenya, but the overall reaction appears more muted than for the transfer of terror suspects. Parisbased Group Says Accused Somali Pirates Denied Rights, Voice of America, Aug. 27, 2009, http://www.voanews.com/english/2009-08-27-voa36.cfm; David Osler, Kenya Trials at Risk of Breaching Human Rights Laws, LLOYD's List, Aug. 25, 2009, http://www.lloydslist.com/ll/ home/blogView.htm?blogId=20001015481.

206. The U.S. transfer in 2006 was thought to be the first of its kind.

207. UNCLOS, supra note 8, art. 105 (emphasis added).

208. See Report of THE InT'L LAW CoMm'n, supra note 72, art. 43 (“This article gives any State the right to seize pirate ships (and ships seized by pirates) and to have them adjudicated upon by its courts. This right cannot be exercised at a place under the jurisdiction of another State.") (emphasis added).

209. Similarly, one of the difficulties of the current War on Terror is fitting new kinds of problems, like terrorist groups with global reach, into older legal instruments like the Geneva Conventions. 
unlikely in practice to hamstring the Kenyan prosecutions, the uncertain language may make other third-party states hesitant to accept such cases. ${ }^{210}$

Although UNCLOS does not explicitly authorize prosecution by thirdparty states, it does not expressly prohibit the practice. ${ }^{211}$ Article 105 could be read to mean that states may not try pirates onboard the captured vessel. According to the preceding article, Article $104,{ }^{212}$ pirated ships retain their nationality - a change from prior customary law. Read together with Article 105 , this would make them an improper venue for trial. ${ }^{213}$ While this reading is plausible, it is not clear whether a court martial on board a seized pirated ship, as opposed to onboard the arresting one, was ever so common a practice to warrant explicit disapproval in articles that otherwise say nothing about the details of prosecution. There is nothing in the drafting history of the provision, which was taken directly from the 1958 Law of the Sea treaty, to support this interpretation. ${ }^{214}$

In short, the text of UNCLOS muddies the question of third-state jurisdiction. ${ }^{215}$ The problems posed by UNCLOS help explain the emphasis that military and diplomatic officials have been placing on SUA, ${ }^{216}$ which allows any signatory state with personal jurisdiction over a defendant to prosecute. $^{217}$ While there is no state practice explicitly elucidating the provision, in the Somali context, most states have not adopted the limited reading of Article 105. This can be inferred from the transfer deals between

210. Int'l Expert Group on Piracy off the Somali Coast, Final Report, Piracy off the Somali Coast: Workshop commissioned by the Special Representative of the Secretary General OF the U.N. to Somalia 7 (2008), available at http://www.imcsnet.org/imcs/docs/somalia_piracy_intl_experts_report_consolidated.pdf ("Neither the LOSC nor the High Seas Convention directly address the transfer of suspects ashore.").

211. Compare Treves, supra note 74, at 408 ("The rule in Article 105 does not, however, establish the exclusive jurisdiction of the seizing state's courts. Courts of other states are not precluded from exercising jurisdiction under conditions which they establish.”), with Milena Sterio, Fighting Piracy in Somalia (and Elsewhere): Why More Is Needed 14 (Cleveland-Marshall Legal Studies Paper No. 09-178, 2009), available at http://papers.ssrn.com/sol3/papers.cfm? abstract_id=1468021 ("Under UNCLOS, the legality of this type of transfer is dubious.").

212. See UNCLOS, supra note 8, art. 104 ("A ship or aircraft may retain its nationality although it has become a pirate ship or aircraft. The retention or loss of nationality is determined by the law of the State from which such nationality was derived.”).

213. See Report of the Int'L LaW Comm'N, supra note 72, art. 43 cmt.

214. 3 United Nations Convention on the Law of the Sea, i982: A Commentary 212-15 (Myron Nordquist ed., 1995).

215. Lawrence Azubuike, International Law Regime Against Piracy, 15 AnN. Surv. InT'L \& Comp. L. 43, 54-55 (2009) (describing the view that noncapturing states lack jurisdiction as "plausible” but by "no means compelling” given the longstanding customary norm of universal jurisdiction).

216. See Countering PIRACY, supra note 7; Baumgartner Statement, supra note 54 (“A key component of the proposed consequence delivery system advocates application of the SUA Convention.”).

217. See SUA art. 6(1), supra note 80, at 669 (allowing any state party to prosecute defendants found in their territory); id. art. 8, at 669 (allowing suspects to be turned over to any state party by master of vessel); id. art. 11 (allowing for extradition of suspects to any flag state). 
Kenya and numerous countries, to which there has been little or no objection on Article 105 grounds. Yet given that in the current situation no state has any self-interested reason for raising such objections (given their unwillingness to try the detainees domestically), such an argument would most probably first be made — and may yet be made — as a challenge to Kenya's jurisdiction by the defendants on trial there.

One way of reconciling the article's language and current practice would be to conclude that UNCLOS, and Article 105 in particular, does not preempt or displace preexisting customary law, which may have given universal jurisdiction authority to any state. (If the authority of jurisdiction of third states comes from custom rather than treaty, this may have implications for their ability to prosecute under their domestic law.) If Kenya's jurisdiction comes from custom, one would have to consider the current custom in modern universal jurisdiction cases regarding which nation should exercise universal jurisdiction. ${ }^{218}$ Modern practice and theory suggests a state with some connection to the offender or conduct should prosecute over a state with no connection. ${ }^{219}$

A limitation of universal jurisdiction to the capturing state would not be anomalous as a policy matter. Apart from nations with traditional jurisdiction, that state would usually have the greatest connection to the offense. The purpose of universal jurisdiction is to enable nations that encounter suspected pirates not to limit their enforcement efforts out of jurisdictional concerns. If nations that make the arrest are unwilling to prosecute, then releasing the defendant may be a proper outcome-a legitimate exercise of prosecutorial discretion. Auctioning prosecution to the lowest bidder, while defensible, can also raise concerns about due process and related issues.

\section{F. Inconsistent Assertions of Universal Jurisdiction}

Prosecuting pirates may be difficult, but it is not impossible. Western nations do not hesitate to bring charges against Somalis that attack ${ }^{220}$ their own vessels. Indeed, European nations have used universal jurisdiction to prosecute other crimes, such as war crimes and torture. Because these offenses, unlike

218. See Peter Csonka, Eur. Comm'n, Piracy and Armed Robbery Against Shipping, Briefing on International Piracy (Jan. 21, 2009), available at http://ec.europa.eu/ transport/maritime/events/doc/2009_01_21_piracy/jls_presentation_csonka_legal_aspects.pdf

(" $[\mathrm{H}]$ ad the universal jurisdiction over pirates been absolute any state of the world could have issued arrest warrants against pirates. State practice, however, does not show any such trend, and this bears out the 'conditional' nature of such category of universal jurisdiction.").

219. See Principle No. 8, Princeton Principles of Universal Jurisdiction, in Universal Jurisdiction: National Courts and the Prosecution of Serious Crimes Under International Law 23 (Stephen Macedo ed., 2006); see also Anne-Marrie Slaughter, Defining the Limits: Universal Jurisdiction and National Courts, in id. at 172-73.

220. See, e.g., Daniel Woolls, Spain Moves to Win Hostage Sailors' Freedom, Associated Press, Nov. 16, 2009 (reporting on Spanish charges against Somali accused of attacking Spanish fishing vessel). 
piracy, take place entirely within the territory of foreign countries and often involve governmental actors as defendants, they raise even greater difficulties for putting together a trial. European countries' avoidance of universal jurisdiction over pirates, even when they actually have the pirates in custody, raises questions about why they are willing to use it in what might seem more difficult and politicized cases. Under the slogan "an end to impunity," universal jurisdiction seeks to address some of the most bloody wars, genocides, and intractable ethnic conflict in the world. ${ }^{221}$ European countries have launched prosecutions against political and military leaders of various distant countries. $^{222}$

Yet the countries at the forefront of expanding universal jurisdiction will not use it to prosecute piracy even though it means allowing a major international problem to go on unchecked. For example, Denmark has said that it cannot punish pirates it captures. ${ }^{223}$ Yet it was one of the first European countries to prosecute Serb officers for crimes committed against Bosnian Muslims in the Yugoslav civil war. ${ }^{224}$ Similarly, when the Spanish Navy captured a group of suspected Somali pirates, a judge ordered them released on the grounds that prosecuting a crime that occurred thousands of miles away would be "a bit disproportionate.",225 Just a week before, another Spanish magistrate had launched an investigation into an Israeli strike on a Hamas leader in Gaza in 2002. ${ }^{226}$

Ironically, Spain lacked personal jurisdiction over the Israeli officials, unlike the pirates. ${ }^{227}$ Moreover, the evidentiary and other practical issues seem

221. See, e.g., Stephen Macedo, Universal Jurisdiction: National Courts and the Prosecution of Serious Crimes Under International Law 5 (2006) (describing “universal jurisdiction as . . . part of a wider set of political and legal movements to expand legal accountability and the global rule of law, and thereby to end impunity for serious crimes under international law”).

222. Jonny Paul, Army Pays Price for Honoring Int'l Law, Jerusalem Post.Com, Nov. 30, 2008, http:/www.jpost.com/servlet/Satellite?pagename=JPost/JPArticle/ShowFull\&cid=122770 2364476 .

223. Julian Isherwood, Pirates Released on Beach, Politiken, Sept. 24, 2008, http://politiken.dk/newsinenglish/article572053.ece.

224. See Luc REydAMs, UnIVERSAL JURISDICTION: INTERNATIONAL AND MUNICIPAL Perspectives 128-29 (2003). To be sure, in European civil law jurisdictions, prosecution requires an affirmative statute. The Danish universal jurisdiction law appears to authorize prosecution only when it is mandated, rather than permitted, by international law. See id. But such statutory lacunae can be easily corrected where there is a political interest in prosecuting.

225. Brian Reyes, Spain Judge Hands over Somali Pirates, Lloyd's List, May 8, 2009, http://www.lloydslist.com/ll/news/spain-judge-hands-over-somali-pirates-to-kenya/20017648702. htm\%3Bjsessionid=F27F836B87FE26232224D8DC27830EEE; Daniel Woolls, Spain: About Face on Piracy Suspects, Chicago Defender, May 8, 2009, http://www.chicagodefender.com/ article-4353-spain-about-face-on-piracy-suspects.html.

226. Craig Whitlock, Spain's Judges Cross Borders in Rights Case; High-Ranking U.S. Officials Among Targets of Inquiries, WAsh. Post, May 24, 2009, at A1.

227. The Geneva Conventions do not appear to authorize universal jurisdiction in abstentia. See Geneva Convention Relative to the Protection of Civilian Persons in Time of War (Fourth Geneva Convention) art. 147, Aug. 12, 1949, 75 U.N.T.S. 287. 
much more daunting when it comes to discerning what happened years ago in an ongoing conflict between Israel and the Palestinians, a situation in which, unlike piracy, some of the alleged victims are actively involved in the conflict and collecting evidence and testimony is inherently politicized. Additionally, unlike with Gulf of Aden piracy, Spain has not been involved in keeping Gaza safe; its judicial interest is unlinked to enforcement activities. Using universal jurisdiction to prosecute crimes in politically fraught Gaza while rejecting it for piracy is like a district attorney prosecuting only high-profile celebrity cases, while letting ordinary murder and robbery go unpunished.

\section{G. Summary}

Capturing pirates raises a host of legal problems. If prosecution appears to be a bad option-because of a lack of evidence, the cost of presenting the evidence, the danger of asylum requests, or the strain on military operationsthe captor must then figure out what to do with the pirate. In the meantime, the detaining power is stuck holding the foreign citizen captured abroad without trial. In the shadow of Guantánamo, which turned the detention and potential trial of alleged combatants into one of the most politically explosive issues of the day, it is understandable that nations choose to ignore their international obligation to fight piracy. Yet the same nations' willingness to use universal jurisdiction in more politically sensitive and legally difficult cases raises questions about the exercise of prosecutorial discretion in universal jurisdiction cases.

\section{CONCLUSION}

The failure of the international response to piracy is a cautionary tale about the limits of international law. It is not that treating pirates as ordinary criminals has proven ineffective. Rather, nations think it would be so difficult to bring these criminals to justice that they are not interested in even trying. Or, to put it differently, while the crime is nominally an injury to all countries and the international legal order, individual states perceive few benefits to enforcing the norm themselves. Indeed, nations treat any option as superior to trials in capturing nations' domestic courts: countries have experimented with renditions to poor third-countries, sought authorization for military strikes, discussed creating a new specialized international court, and even released pirates shortly after their capture.

Ironically, many commentators have claimed that some problems of dealing with international terrorists could be partially resolved by giving them the legal status of pirates. ${ }^{228}$ They argue that just as international law allows

228. See, e.g., Burgess, supra note 6; Anthony J. Colangelo, Constitutional Limits on Extraterritorial Jurisdiction: Terrorism and the Intersection of National and International Law, 48 Harv. InT'L L.J. 121, 201 (2007); Ingrid Detter, The Law of War and Illegal Combatants, 75 
universal jurisdiction over pirates - violent nonstate actors with transborder operations-it should extend universal jurisdiction to terrorists. The longstanding status of piracy as the paradigmatic international crime made it seem a safe model to extend to a more difficult context. But while the treatment of piracy does have lessons for the War on Terror, they are not lessons for emulation.

Even as international law has progressed, it has developed in such a way that it cannot respond effectively to an atavism like piracy. Further, the difficulties of prosecuting pirates are likely minimal compared to those difficulties involved in prosecuting trained terrorists. The piracy problem raises questions about the ability of the liberal international law regime to deal with organized and violent transnational networks. The purely military justice model for prosecuting hostile foreign irregulars that Guantánamo came to symbolize has proven politically unacceptable in the United States and other Western democracies. Yet the current piracy efforts suggest the great practical difficulties in applying a civilian enforcement model to a large number of individuals. The unattractiveness of either option suggests that many of the foundational instruments of modern international law need retooling to meet changing threats. If international justice fails against "criminal activity by lightly armed thugs deployed from small boats and fishing vessels,"229 it will be hard for it to deter more formidable wrongdoers. If a small number of robbers cannot be brought to the bar of international justice, the war criminals of the world have little to worry about.

Geo. Wash. L. Rev. 1049, 1096-1101 (2007); Morris L. Sinor \& Robin M. Blackwood, Confronting Nomadic Terrorism, 52 Naval L. Rev. 98, 117 (2005). These arguments were generally made before the current spike in incidents of piracy and the subsequent failure of states to address piracy through judicial means.

229. Baumgartner Statement, supra note 54. 
[Vol. 98:243 